\title{
Is Investment-Cash Flow Sensitivity Caused by Agency Costs or Asymmetric Information? Evidence from the UK
}

\author{
Grzegorz Pawlina* \\ Department of Accounting and Finance, Lancaster University, LA1 4YX, United Kingdom \\ email: g.pawlina@lancaster.ac.uk
}

\section{Luc Renneboog}

Department of Finance, CentER and TILEC, Tilburg University, and ECGI, P.O. Box 90153,5000 LE, Tilburg, the Netherlands

email: luc.renneboog@uvt.nl

\section{Forthcoming in European Financial Management}

\begin{abstract}
We investigate the investment-cash flow sensitivity of a large sample of the UK listed firms and confirm that investment is strongly cash flow-sensitive. Is this sensitivity a result of agency problems when managers with high discretion overinvest, or of asymmetric information when managers owning equity are underinvesting if the market (erroneously) demands too high a risk premium? We find that investment-cash flow sensitivity results mainly from the agency costs of free cash flow. The magnitude of the relationship depends on insider ownership in a non-monotonic way. Furthermore, we obtain that outside blockholders, such as financial institutions, the government, and industrial firms (only at high control levels), reduce the cash flow sensitivity of investment via effective monitoring. Finally, financial institutions appear to play a role in mitigating informational asymmetries between firms and capital markets. We corroborate our findings by performing additional tests based on the stochastic efficient frontier approach and power indices.
\end{abstract}

Keywords: investment-cash flow sensitivity; ownership and control; asymmetric information; liquidity constraints; agency costs of free cash flow; large shareholder monitoring; Shapley values.

JEL classification: $D 92, G 31, G 32$

\footnotetext{
* Corresponding author. Grzegorz Pawlina recognizes support from the European Union's Phare ACE Programme. Luc Renneboog is grateful for financial support by the Netherlands Organisation for Scientific Research and to European Commission's FP6 project 'New Modes of Governance' (coordinated by the RSCAS of the European University Institute). The content of this paper is the sole responsibility of the authors and does not represent the views of the Commission or its services. The authors are grateful to John Doukas, Carles Gispert, Marc Goergen, Klaus Gugler, Harijono Harijono, Abe de Jong, Joe McCahery, Chris Veld, an anonymous referee and participants of the Investment and Corporate Governance Workshop in Cambridge and the European Financial Management Association Annual Meeting in Basle for helpful comments. All remaining errors are ours.
} 


\section{Introduction}

In perfect and complete markets, investment decisions of a firm are independent from its financial situation (Modigliani and Miller, 1958). Firms undertake investment projects if and only if the present value of discounted cash flows exceeds the associated capital expenditure. Moreover, there is no capital rationing since firms can always obtain external financing at a cost equal to their (true) cost of capital. However, in imperfect or incomplete markets the financial structure of a firm becomes relevant. For example, if the capital markets' participants face significant uncertainty about the firm's future prospects, the cost of external capital often exceeds the cost of internal financing.

In general, there are a number of factors that make a firm's investment policy depend on its financial position. According to Jensen and Meckling (1976), owners-managers of a levered firm tend to overinvest and choose too risky (and often negative NPV) projects due to their limited liability. Myers (1977) shows that capital structure can influence investment decisions even without apparent market imperfections: risky debt may lead to underinvestment due to the wealth transfer from shareholders to creditors that occurs upon investment. Myers and Majluf (1984) obtain that asymmetric information between a firm and the capital markets may result in the rejection of good investment opportunities because the providers of external capital include into the cost of capital a risk premium reflecting the risk of an average investment project. A similar rationale is developed by Stiglitz and Weiss (1981), who describe how asymmetric information may result in the rationing of debt finance. Finally, according to Jensen (1986), suboptimal investment can occur due to agency costs between shareholders and management, when the latter's objective function does not reflect the interests of shareholders.

While the above shows that investment policy can be explained by many theories involving the choice of financing (debt versus equity, outside equity versus internally generated funds), agency costs (management versus monitoring blockholders), asymmetric information (between management and the providers of external equity) and moral hazard (the choice of risk of an investment project), we address a narrower research question in this paper. Namely, we investigate the reasons why the level of corporate investment is sensitive to the firm's available free cash flow, as observed in their seminal work by Fazzari, Hubbard and Petersen (hereafter FHP, 1988). In principle, this sensitivity 
will be observed if (i) there is a wedge between the cost of internal and external financing, and (ii) the decision to spend a marginal unit of internally generated funds is consistent with the utility maximization problem of top management. Consequently, the observed sensitivity can be attributed either to asymmetric information problems (Myers and Majluf, 1984; Stiglitz and Weiss, 1981) or to agency costs of free cash flow (Jensen, 1986), for which conditions (i) and (ii) are satisfied. ${ }^{1}$ In general, it is possible that some firms exhibit a high investment-cash flow sensitivity due to informational asymmetries (such firms would underinvest), whereas others may suffer from overinvestment attributable to the agency costs of free cash flow. ${ }^{2}$

Asymmetric information may lead to the rejection of good investment opportunities because external financing may be deemed overly expensive by the management (whose information is mostly superior to that of outside investors, cf. Myers and Majluf, 1984; Myers, 1984). As the market is less well-informed about the firm's or the project's quality, it may demand a premium on the capital provided that is equal to the premium charged to the median firm. This mechanism may lead to adverse selection among the firms applying for external financing. As a result, a fraction of good investment projects which are not profitable enough to compensate for the excessively high cost of external financing (compared to the perfect information situation) are foregone. In this situation, asymmetric information leads to an underinvestment problem. $^{3}$

Another source of the investment-cash flow sensitivity is the agency conflict between shareholders and management (Jensen, 1986, 2001; Bernanke and Gertler, 1989; Stulz, 1990). Corporate managers' interests may not be perfectly aligned to the interests of shareholders as the utility managers derive from managing firms has been shown to be an increasing function of the corporations' size (as pecuniary and non-pecuniary managerial benefits are higher in larger companies than in smaller ones, see e.g. Conyon and Murphy, 2000; Renneboog and Trojanowski, 2004). Therefore, management's corporate objective may be growth rather than value. As a consequence, negative net present value investments could also be undertaken resulting in overinvestment.

This study has the following aims. First, we investigate whether the widely-documented positive relation between corporate investment and liquidity (as demonstrated for the US in FHP, 
1988, see also a survey by Hubbard, 1999) is also present in the UK. We do so by estimating the standard reduced-form investment $q$-model, which controls for firms' investment opportunities.

Second, unlike most past investment research (cf. Vogt, 1994; Hadlock, 1998; Morgado and Pindado, 2003), we use multiple criteria to identify whether investment-cash flow sensitivity is caused by asymmetric information or it results from the agency cost of free cash flow. To achieve our objective, we analyze the influence of ownership and control structures, growth opportunities and a firm's technical efficiency of deploying its assets on the relationship between the investment level and liquidity. More specifically, we focus on (i) the distribution of voting rights over different types of large shareholders, (ii) the interaction of the cash flow sensitivity and the firm's growth opportunities under different ownership and control patterns and (iii) the impact of technical efficiency on this interaction. Our results provide strong support for the free cash flow theory as the main source of the observed investment-cash flow sensitivity. We also find some support for the asymmetric information hypothesis for a group of companies largely controlled by financial institutions.

We test our hypotheses on a large sample of 985 firms listed on the London Stock Exchange over period 1992-98. This period is interesting for two reasons. First, it corresponds to an economic boom period during which liquidity constraints may be binding for expanding firms. Second, it embeds a period of improving corporate governance standards. Since July 1993, all listed firms are obliged to comply with the recommendations of the Cadbury Committee (published in December 1992). ${ }^{4}$

Relatively few papers test the investment-liquidity relation in a corporate governance framework. Recent exceptions include Kathuria and Mueller (1995), Hadlock (1998), and Gugler and Yurtoglu (2003), for the US, Gugler (2003) for Austria, Haid and Weigand (2001) for Germany, Degryse and de Jong (2000) for the Netherlands, Pindado and de la Torre (2004) for Spain, and Goergen and Renneboog (2001) for the UK.

This paper contributes to the existing literature in three ways. Firstly, it distinguishes between investment inefficiencies induced by agency cost of free cash flow and asymmetric information. Secondly, it explores a large sample covering more than $85 \%$ of the market 
capitalization of UK industrial firms, for which a unique ownership database has been compiled. Thirdly, it partially relies on such techniques as the stochastic frontier approach (SFA) and the Shapley value methodology, which are novel to or largely unexploited in corporate investment research.

We find that the relationship between cash flow sensitivity and insider control reflects the interplay of managerial alignment of interests and entrenchment. ${ }^{5}$ The interpretation of our results consistent with Jensen's (1986) free cash flow theory indicates that at increasing share stakes managers' interests become aligned with those of the shareholders and remain such for very high levels of insider ownership. At the same time, managerial entrenchment is likely to emerge at moderate to higher managerial equity stakes.

Secondly, we find that the presence of large outside blockholders (and the related monitoring) mitigates the free cash flow problem. This is due to the blockholders' incentive to monitor being positively related to their equity participation since the benefits of monitoring are proportional to the shareholding whereas the costs are independent from it and are borne by the shareholder in their entirety (cf. Grossman and Hart, 1980; Demsetz, 1983). Furthermore, we provide some support for the hypothesis that the presence of institutional blockholders facilitates the access to external financing, hence decreasing the reliance of a firm's investments on internal cash flow (cf. Hoshi, Kashyap and Scharfstein, 1991).

Subsequently, using the stochastic efficient frontier methodology, we find a negative relationship between the investment-cash flow sensitivity and corporate efficiency. This supports our earlier result that firms whose investment is sensitive to cash flow, suffer from agency problems, which is ultimately reflected in lower valuations. Finally, by analyzing firms pursuing different share repurchase and dividend policies, we provide evidence that observed cash flow sensitivity does reflect liquidity constraints. ${ }^{6}$

The remainder of the paper is organized as follows. In Section 2, we discuss the relevant literature, while in Section 3, we formulate our hypotheses. Section 4 contains the description of the data set and methodology. In Section 5, we present our main results and Section 6 concludes. 


\section{Literature}

Fazzari, Hubbard and Petersen (hereafter FHP, 1988) open the debate on the impact of financing constraints on the investment level. They test the relationship between liquidity and capital expenditure for a sample of US manufacturing firms. The firms are classified into three categories based on the long-term dividend ratio, a proxy for financing constraints. FHP (1988) regress investment on cash flow and Tobin's $q$ and obtain that the sensitivity of capital expenditures with respect to cash flow fluctuations is the highest in a subsample of low-dividend firms. Fazzari and Petersen (1993) provide further support for the liquidity constraints hypothesis of FHP (1988) by analyzing the role of working capital as a use of funds. Their study concludes that the investment of low-dividend firms appear to be more cash flow sensitive and that working capital does seem to compete with fixed investment for funds.

Carpenter (1995) is one of the first authors who attempts to determine why liquidity constraints result in the cash flow sensitivity of investment. For a sample of big and mature low- $q$ firms, he analyses debt-for-equity swaps, which can be viewed as a way to improve managerial efficiency by reducing free cash flow. A lower dependence of investment on available funds following the swap suggests the presence of overinvestment prior to the restructuring. Additional support for the free cash flow-based explanation is provided by Kadapakkam, Kumar and Riddick (1998), who use the sample of firms from 6 OECD countries. Kadappakkam et al. report that investment of larger firms exhibits higher cash flow sensitivity. This is consistent with a view that managers of large firms that experience more serious agency problems of free cash flow, tend to expand the firm size whenever internal funds are available.

In a paper on Japanese firms, Hoshi, Kashyap and Scharfstein (1991) extend the analysis by considering a corporate control framework, namely the firms' relations with large banks belonging to large industrial groups (keiretsu). Keiretsu firms have closer ties to banks and hence easier access to external financing, which reduces liquidity constraints. Hoshi et al. confirm a lower investment-cash flow sensitivity of keiretsu members, which is in line with the asymmetric information hypothesis. Support for this hypothesis is also provided by Hadlock (1998), who studies the impact of insider shareholdings on the investment-cash flow sensitivity of US firms. The author finds an inverted U- 
shaped relationship, which indicates that $i$ ) management's participation in equity makes them more sensitive to the premium charged by the market on external financing, and that ii) entrenchment, which occurs at the higher ownership levels, reverses this relationship.

Kaplan and Zingales (hereafter KZ, 1997) present a critique of FHP (1988) and of related articles, which claim that the cash flow sensitivity of corporate investment reflects financing constraints faced by the firm. Using the subsample of firms used by FHP (1988), KZ (1997) analyze both quantitative and qualitative information on firms and find that less constrained companies exhibit significantly higher cash flow sensitivity of investment. FHP (2000) respond by indicating a number of inconsistencies in the KZ (1997) approach, using a small sample that is not sufficiently heterogeneous for drawing meaningful conclusions, and classifying firms with respect to the degree of financing constraints using fairly subjective set of criteria.

Cleary (1999) contributes to the FHP-KZ debate by proxying the level of financing constraints with the firms' creditworthiness measured by the Altman Z-score. He finds the highest investment-cash flow sensitivity for the subsample of non-constrained firms, which supports $\mathrm{KZ}$ (1997). More recent contributions, such as Alti (2003), and Gomes (2001) provide mixed conclusions about the role of financing constraints in generating high investment-cash flow sensitivities. Using a simulation approach, Moyen (2004) reconciles the results of FHP (1988) and KZ (1997) by using subsamples without and with, respectively, a priori imposed financial constraints. Almeida and Campello (2002) obtain that credit-constrained firms exhibit higher sensitivity than those with free access to capital markets. Using the real options framework, Boyle and Guthrie (2003) show that relatively unconstrained firms do overinvest, however, the magnitude of overinvestment in those firms is positively related to the degree of financing constraints.

To summarize, the existing literature confirms the existence of the positive investment-cash flow sensitivity, identifies that it can be based on the agency cost of free cash flow and/or asymmetric information, but fails to resolve under which circumstances it is related to the liquidity constraints. Since both agency theoretical and asymmetric information-based explanations of the cash flow sensitivity of investment rely on the assumption of a costly access to external capital, a properly 
designed empirical attempt to disentangle those two hypotheses should also verify that liquidity constraints are a driving force of the sensitivity observed in the sample.

\section{Hypotheses}

\subsection{Agency cost of free cash flow}

High free cash flows may tempt management to pursue an 'empire building'-strategy (Grossman and Hart, 1982) and, hence, to overinvest (Jensen, 1986). The reason for this agency problem is that management not only receives a higher remuneration in larger firms (Conyon and Murphy, 2000), but that management may also be able to extract private benefits of control (which may be nonpecuniary, like prestige) from managing larger firms (Dyck and Zingales, 2004). Thus, a high amount of corporate liquidity may encourage growth-maximizing management to pursue investment projects with an expected rate of return below the hurdle rate. This free cash flow-agency problem reflected in a positive relation between cash flow and investment is expected to be more substantial in widelyheld companies with low managerial ownership. The investment-cash flow sensitivity is likely to initially decrease with increasing managerial ownership as co-ownership is expected to turn the management's focus to shareholder value maximization. This is due to the fact that alignment of interests will prevent management from squandering extra cash flow on unprofitable projects. Hence, we expect an initially negative relationship between the investment-cash flow sensitivity and insider ownership due to better alignment of interests and lower agency costs (Hypothesis 1a).

The investment-cash flow sensitivity is not expected to decrease monotonically with rising insider control. At higher levels of managerial ownership, a second type of agency problem may arise: entrenched managers may expropriate the rights of minority shareholders (for examples see Johnson et al., 2000) and pursue too aggressive an investment policy. This may result in the investment-cash flow sensitivity increasing for moderate to high levels of managerial ownership. ${ }^{7}$ Finally, if the managerial ownership becomes sufficiently high, that is, when management internalizes a large fraction of the changes in the firm's value resulting from suboptimal investments, the investment-cash flow sensitivity will decrease (cf. Morck et al., 1988). Hence, we expect an $S$ - 
shaped relationship between the investment-cash flow sensitivity and insider ownership due to the magnitude of the agency cost of free cash flow changing with insider ownership (Hypothesis $1 b$ ).

Corporate monitoring by large outside shareholders and by non-executive directors is expected to attenuate the agency conflicts between management and shareholders. The costs of free cash flow may be reduced when shareholders perform an active monitoring role (Lasfer, 1995). Existing empirical evidence for the UK shows that industrial corporations as well as individuals (not related to the firm's top management) owning large share blocks discipline incumbent management in the wake of a performance decline and in the absence of managerial entrenchment (see Franks, Mayer and Renneboog, 2001). Since a shareholder internalizes the entire cost related to her control efforts but benefits only in proportion to her share stake (Grossman and Hart, 1980; Demsetz, 1983), monitoring will only be cost effective if this shareholder becomes sufficiently large. ${ }^{8}$ Hence, we expect that blockholder monitoring reduces agency costs and, hence, the investment-cash flow sensitivity (Hypothesis 1c).

The agency-related overinvestment problem is more serious in mature firms with low growth perspectives (Jensen, 1986; Carpenter, 1995). Those low- $q$ firms suffer from a shortage of positive NPV projects. As a result, it may be that extra cash flow generated may be squandered by its managers on value-destroying projects (see Vogt, 1994). In other words, for low- $q$ firms, the availability of additional cash flow may be associated with excess investment spending. Hence, we expect a higher investment-cash flow sensitivity for low-q firms (Hypothesis 1d).

If managers run companies efficiently, they do not exhibit empire-building behavior and their investment policies are not related to the internally generated cash flow. Consequently, in firms where the observed Tobin's $q$ is close to the efficient $q$, the investment policy should not be sensitive to liquidity. High efficiency means that the firm resources are not wasted by overspending management. One should be able to observe this most clearly in the low- $q$ firms, which are more prone to the free cash flow problem. Hence, we expect a negative relation between cash flow sensitivity and technical efficiency for low-q firms, which reflects the diminishing agency costs of free cash flow (Hypothesis 1e). 


\subsection{Asymmetric Information}

A shortage of internally generated funds will lead to corporate underinvestment due to asymmetric information (Myers and Majluf, 1984). This occurs when a firm faces insufficient funds to finance an investment project and when the financial markets to which the management turns to attract additional funds, have less information about the true NPV of the project. Even for high quality projects, the less-informed financial markets demand a risk premium that reflects average project quality. This risk premium may be deemed excessively high for some projects that actually do pass the management's hurdle rate which correctly reflects the project's risk. ${ }^{9}$ Consequently, management may be forced to pass over some positive NPV projects as a consequence of asymmetric information. This underinvestment problem is expected to be more important when the management of an otherwise widely-held firm controls a large equity stake (Hadlock, 1998). The positive relationship between cash flow and corporate investment induced by asymmetric information will decrease with falling levels of insider ownership. When the management owns only a small stake in a widely held firm, it may accept the (excessive) risk premium of the financial markets and knowingly invest in, effectively, negative NPV projects. Hence, we expect an initially positive relationship between investment-cash flow sensitivity and insider ownership due to management internalizing a higher fraction of the premium on external capital (Hypothesis $2 a$ ).

The underinvestment problem described in Hypothesis 2a will be attenuated if a block of the firm's shares is held by a financial institution. Kahn and Winton (1998) argue that the large blockholding of a financial institution reduces the informational asymmetry between the institution and the firm. Combined with the result of Shleifer and Vishny (1986), who state that a shareholder has an incentive to gather information about the firm if their stake is sufficiently large, blockholding by financial institutions is expected to reduce informational asymmetries between the firm and the capital market due to institutions' expertise and active capital market participation. In such a case, the firm could rely more heavily on external sources of financing, of which cost will be closer to the firm's true cost of capital (Hoshi et al., 1991). Consequently, we hypothesize that the presence of a financial institution reduces the asymmetric information problem, underinvestment, and the resulting 
investment-cash flow sensitivity. Hence, we expect a negative relationship between institutional blockholding and investment-cash flow sensitivity (Hypothesis 2b).

When liquidity constraints are present, the underinvestment problem is expected to be more outspoken for high growth companies. This is due to the fact that the informational asymmetry is more severe when a large proportion of the firm's value can be attributed to growth opportunities of which the quality is to a large extent unverifiable ex ante (cf. Myers and Majluf, 1984). Furthermore, a closely related argument is that the relative amount of collateral that those companies are able to pledge is limited (cf. Almeida and Campello, 2004). This makes the cost of external financing higher, which, in turn, results in a stronger relationship between the internally generated cash flow and investment. Hence, we expect a higher investment-cash flow sensitivity of high-q firms (Hypothesis $2 c)$.

Finally, while high- $q$ firms are in general more prone to asymmetric information problems, the problem of asymmetric information and the resulting high risk premium which causes the underinvestment problem, may be reduced in firms with investment opportunities recognized by the market. If corporate efficiency is somehow observed by the market (i.e. Tobin's $q$ is close to the efficient $q$ ), we should observe a negative relationship between investment-cash flow sensitivity and technical efficiency, measured by the ratio of Tobin's $q$ to efficient $q$. Hence, we expect a negative relation between cash flow sensitivity and technical efficiency for high-q firms, reflecting diminishing informational asymmetry (Hypothesis 2d).

\subsection{Financing constraints}

Since both the free cash flow theory and asymmetric information hypothesis rely on the assumption that the cost of external financing exceeds the cost of internally generated funds, we test whether the observed relationship can be attributed to liquidity constraints. Firms that are the most likely candidates as being liquidity constrained are those firms that reduce dividends or refrain from repurchasing their shares (cf. FHP, 1988; Goergen and Renneboog, 2001; Correia da Silva et al., 2004). Evidence of a significantly higher cash flow sensitivity for liquidity constrained firms would support the hypothesis that the sensitivity is generated by a need of funds, and not other factors, such 
as cash flow proxying for investment opportunities failed to be captured by market-to-book value ratio, or the capital structure adjustments (Moyen, 2004). Hence, we expect a negative relationship between dividend increases/share repurchases and investment-cash flow sensitivity (Hypothesis 3).

\section{Data and methodology}

\subsection{Data sources and variable description}

Of all the firms listed on the London Stock Exchange, we exclude banks, insurance companies, and other financial firms as the type of corporate investments and accounting data differ from those of industrial and commercial firms. We also exclude utilities of which the investment behavior and access to external financing is regulated. We also only retain firms for which we have ownership data were available in the Worldscope Disclosure data set over the period 1992-1998. Our sample consists of 985 UK firms listed on the London Stock Exchange and includes 206 agricultural, mining, forestry, fishing and construction firms (SIC codes 1-1999), 407 manufacturing firms (SIC codes 2000-3999), 204 retail and wholesale firms (SIC codes 5000-5999) and 168 service firms (SIC codes 7000-8999).

Descriptive statistics of the data are included in Table 1 (currency denominated items are in GBP '000s). The average and median investment of our sample firms amount to, respectively, 9.7\% and $4.4 \%$ of the capital stock while the median cash flow standardized by capital is $42 \%$. Our proxy for Tobin's $q$, market-to-book value of assets averages 1.87 with a median of 1.45 . The optimally attainable or efficient $q$ is higher with an average of 3.61 and a median of 1.67 (for the calculation methodology, see infra). UK companies pay out about $20 \%$ of earnings in dividends. $70.1 \%$ of firms increase dividends, whereas $16.2 \%$ of firms do not change dividends. $5.8 \%$ of our sample repurchased equity, but the average percentage of equity bought back remained very small at $8.3 \%$ of equity. The variables used in the regression analysis are defined as in the Worldscope database unless stated otherwise.

[Insert Table 1 about here] 
Table 2 shows the evolution of investment levels over the sample period. Both the median and mean levels fluctuate over time. As of 1995, a buoyant economy is further stimulated by increasing investments, which median level amounts to GBP 0.96 million.

[Insert Table 2 about here]

The ownership data, including the name and the percentage of shares held by a given shareholder are collected from Worldscope. We categorized ownership stakes by class of shareholder: (i) institutional investors consisting of banks, investment and pension funds, insurance companies, and real estate firms; (ii) industrial and commercial companies; (iii) individuals and families not related to a director; (iv) government; and (v) insiders (CEO, the chairman, executive directors, and non-executive directors; all including their families). ${ }^{10}$ To distinguish between more than 5000 insider and outsider individual shareholders, we consulted the London Stock Exchange Monitor and the Who's Who-guides. To identify institutional shareholders, we consulted Datastream, Institutional Investors Annual Guides and the world wide web.

The largest owner in the median UK firm owns about $15.5 \%$ (with a mean of about $21 \%$, see Table 3, Panel A). Accumulating all large shareholders who own share stakes of at least 5\%, we find that the average blockholder coalition controls almost $40 \%$ of the voting rights (Panel B). Moreover, there is little variability in accumulated ownership across time. The low median and average Herfindahl index of Panel $\mathrm{C}$ shows that control is not concentrated in the hands of one or two large shareholders but that equity stakes are held by about six large shareholders in most firms.

\section{[Insert Tables 3 and 4 about here]}

Table 4 gives a detailed analysis of ownership by type of owner. Financial institutions are clearly the strongest shareholder class: they are present in most UK firms but their individual stakes are usually smaller than $10 \%$. Corporations control the largest equity stake in only $10 \%$ of listed UK firms, but when they do this shareholding is large (about 30\%). Likewise, families and individuals (not related to a director) own share stakes in a minority of sample firms but usually have a large control stake. Since the privatizations of the 1980s, the government only rarely holds a (small) equity stake in listed firms. An important shareholder class comprises inside shareholders. ${ }^{11}$ 
The one-share-one-vote principle is upheld in listed UK companies as there are no dual class voting shares and as regulation has impeded cascade ownership structures. Still, the percentage of ownership does not necessarily reflect the degree of control as 50\% of equity plus 1 vote yields absolute control. Given that most UK companies are characterized by diffuse ownership structures, a measure needs to be used which captures the true degree of shareholder control. Therefore, we resort to Shapley (1953) values (SVs), which assign a power index to each shareholder that reflects their relative importance in forming winning voting coalitions. ${ }^{12,13}$

Table 4 (Panel D) shows Shapley values categorized by the type of owner. SVs are not additive, but by calculating the SV of a shareholder category we assume that the shareholders of specific categories are more prone to collaborate and to vote together (Crespi and Renneboog, 2002). In other words, in this case we assume that each category (e.g. insiders or corporations) vote together. In such a two-stage game, the relative voting power of categories (here considered as ex ante coalitions) can be calculated. The average SV of insiders is reasonably high: 0.230 (i.e. insiders participating in the wining coalition would collectively receive on average almost one quarter of the surplus from cooperation).

\subsection{Methodology}

\subsubsection{Panel data methodology}

Since our data set contains both cross-sectional and time-series observations, we apply a panel data methodology. We estimate the random-effects model (EGLS) that gives the most efficient parameter estimates (Greene, 2002). Since the EGLS estimator requires for consistency that the vector of explanatory variables be uncorrelated with the error term, we use the Hausman test to verify the null hypothesis that this correlation equals zero. If the null hypothesis is rejected, we use a less efficient but consistent fixed-effects estimator. In each case, we report which estimator is used.

Although our panel data methodology does not eliminate the endogeneity problem, it could be mitigated by replacing the market-to-book ratio at the end of the year for its value at the beginning of the year. 


\subsubsection{Stochastic efficient frontier methodology}

We use the stochastic frontier model to obtain a theoretical measure for Tobin's $q$ under the assumption that a firm utilizes the optimal combination of its inputs. To obtain efficiency estimates we use package FRONTIER 4.1 written by Tim Coelli. Our approach is similar to Habib and Ljungqvist (2005), who calculate the difference between efficient and actual $q$ to measure the extent to which agency problems prevail in the analyzed companies. We apply the Battese and Coelli (1995) model, which assumes that that part of the error term which reflects poor management is drawn from a truncated normal distribution. The way we model the efficient $q$ differs from the approach of Habib and Ljungqvist (2005) with respect to the choice of the set of explanatory variables.

The stochastic frontier model we estimate is

$$
\begin{aligned}
M V_{t} / B V_{t}= & \beta_{0}+\beta_{1} \text { lnSales }_{t}+\beta_{2}\left(\text { lnSales }_{t}\right)^{2}+\beta_{3} I_{t} / K_{t-1}+\beta_{4} K_{t-1} / \text { Sales }_{t} \\
& +\beta_{5} \text { OperMar }_{t}+\beta_{5} \text { LEV }_{t}-v_{t}+\varepsilon_{t}
\end{aligned}
$$

where $M V_{t} / B V_{t}$ is the market-to-book ratio, $\operatorname{lnSales}_{t}$ is the natural logarithm of revenues, $I_{t} / K_{t-1}$ represents the investment-to-capital ratio, $K_{t-1} /$ Sales $_{t}$ is the capital intensity, OperMar $_{t}$ is the operating margin, and $L E V_{t}$ denotes market leverage. To prevent the loss of information when there is missing data in any firm-year, we set the value of the missing observation to zero and set the value of the related dummy variable to one. In Eq. (1), $\varepsilon_{t}$ is a random error distributed according to $N\left(0, \sigma_{\varepsilon}^{2}\right)$ and $v_{t}$ is a non-negative random component that reflects the inefficiencies in operating the company by the management. The random component $v_{i t}$ is distributed according to $N\left(Z_{t} m, \sigma_{v}{ }^{2}\right)$, where $Z_{t}$ denotes the vector of variables affecting the inefficiency level of a given firm, and $m$ is a vector of unknown parameters. In our case, the inefficiency contribution $v_{t}$ is estimated as

$$
v_{t}=\alpha_{0}+\alpha_{1} I N S_{t}+\alpha_{2}\left(I N S_{t}\right)^{2}+\alpha_{3} \text { Block }_{t}+\alpha_{4}\left(\text { Block }_{t}\right)^{2}+u_{t}
$$

$I N S_{t}$ is the insiders' share of stock, and Block ${ }_{t}$ denotes the other blockholders' (not insiders) ownership. $^{14}$

Applying the stochastic frontier methodology to $M V_{t} / B V_{t}$ leads to the estimate of the difference between the stock market valuation and the hypothetical value of a firm if its assets are put to the best possible use. The parameter estimates and their $t$-statistics, are presented in Table 5 
(Panels A and B). The signs of the coefficients of the stochastic frontier seem to be plausible. The positive impact of capital expenditure, and the negative impact of capital intensity and market leverage on the firm's value are consistent with Habib and Ljungqvist (2005).

[Insert Table 5 about here]

The estimated coefficients in the inefficiency model are also of interest. The coefficient of $I N S_{t}$ is positive, which indicates that the firms subject to managerial entrenchment are on average less efficient. However, at high levels of ownership the presence of other blockholder may exacerbate this problem. Despite the fact that both variables taken in isolation are on the brink of statistical significance, the likelihood ratio (LR) test indicates the significance of the set of explanatory variables of the one side-error component (which is equivalent to rejecting null hypothesis that $\alpha_{k}=0$ $\forall k \in\{0,1,2,3,4\})$

The average level of efficiency, denoted by $E F F_{t}$ and obtained by estimating model (1)-(2), equals $0.846 .{ }^{15}$ This implies that the market value of an average firm could be increased by $18.2 \%$ $((1-0.846) / 0.846)$ if all its resources were used efficiently. In absolute terms this percentage correspond to the difference in value of GBP 99.04 million. Descriptive statistics are presented in Table 5 (Panel C). Equipped with an estimate of technical inefficiency for every firm, we introduce a new measure, efficient $q$, defined as $Q^{e f f}{ }_{t} \equiv M V_{t} / B V_{t} *\left(E F F_{t}\right)^{-1}$.

The technical efficiency parameter allows us to predict the degree to which firms suffer from the agency costs of free cash flow and the high premium for external financing, which makes them unable to utilize their resources fully efficiently. To do so, we estimate the cash flow-investment models after categorizing the firms according into the low- $q$ firms (where agency problems are expected to be more prominent) and high- $q$ firms (in which asymmetric information may create underinvestment), and including interaction term $C F_{t} / K_{t-1} * E F F_{t}$.

\section{Results}

The estimation results of the basic investment model $I_{t} / K_{t-1}=b_{0}+b_{1} C F_{t} / K_{t-1}+b_{2} M V_{t-1} / B V_{t-1}+\varepsilon_{t}$ for all 3445 firm-years are presented in Table $6 .{ }^{16} \mathrm{We}$ observe a significantly positive relationship (at the 
$1 \%$ level) between corporate investment and cash flow (see Panel A) after controlling for the firms' investment opportunities captured by Tobin's $q$ (proxied by the beginning-of-the-period market-tobook value ratio). The positive cash flow sensitivity may result from an overinvestment problem (related to the agency cost of free cash flow) or an underinvestment problem (as a consequence of asymmetric information). If agency problems are the predominant reason, we expect the cash flow sensitivity to be higher in the subsample of low insider ownership. With rising levels of managerial ownership, we expect the correlation to decrease because management will be more focused on value creation. The opposite result is expected if, in contrast, asymmetric information is a serious problem.

Subsequently, we analyze how the investment-cash flow sensitivity changes between firms with insider ownership above the median and below median and between firms with high versus low outside block ownership. The interaction dummies of Panel B of Table 6 test for the difference in coefficients across the different subsamples. In the case of weak insider control in widely-held firms the cash flow sensitivity is relatively high and equals 0.096. When insiders own large share blocks, the investment-cash flow sensitivity is much smaller and amounts to $0.096-0.035=0.061$. This corroborates the free cash flow Hypothesis 1a: investment is less dependent on cash flow when management participates in the equity and is thus more focused on value creation. At the same time, these findings do not support Hypothesis 2a which states that increasing insider ownership induces a positive relation between investment and cash flow. The reason is that management may pass over some positive investment projects as their equity ownership makes them internalize a higher fraction of the premium on external capital which may be too high due to asymmetric information between the external capital markets and the management.

The model of Panel B also allows us to investigate the impact of large blockholders on a firm's investment decision. In firms with strong blockholders but low insider ownership, the cash flow coefficient goes down substantially to $0.048(0.096-0.048)$. This shows that even when management does not hold any equity stakes, liquidity-dependent investment will be reduced as a result of reduced agency costs due to increased blockholder monitoring. This strongly supports Hypothesis 1c. Finally, taking into account all interaction dummies (this corresponds to high levels of managerial and outside shareholdings) shows that both types of ownership act as substitutes in 
reducing the investment-cash flow sensitivity. Consequently, the sensitivity in this group equals to 0.065 and is lower than of widely-held firms but does not seem to be a further improvement beyond what is obtained when a single type of blockholdings is present. To summarize, the results presented in Table 6 support the hypothesis that the observed investment-cash flow sensitivity is driven by Jensen's (1986) overinvestment problem.

\section{[Insert Table 6 about here]}

Hypothesis $1 \mathrm{~b}$ states that the relation between cash flow sensitivity and insider ownership is non-monotonic (S-shaped) due to a change in magnitude of the interests' alignment of management and shareholders and due to the possible emergence of managerial entrenchment. To test this hypothesis, we first estimate an investment model which includes interactive terms of (insider) ownership and cash flow. The cubic form of the model for insider ownership is designed to provide sufficient flexibility to capture the hypothesized S-shaped cash flow sensitivity-ownership relationship (Hypothesis 1b). The quadratic form of the model for other types of blockholdings is flexible enough to detect potential expropriation effects at the high ownership levels (Shleifer and Vishny, 1997; Johnson et al., 2000). The estimated coefficients indicate a non-monotonic between insider ownership and investment-cash flow sensitivity (Table 7, Panel A), consistent with McConnell and Servaes (1990). However, only the linear term in on the brink of statistical significance, whereas the quadratic and cubic terms do not significantly differ from zero. Therefore, the results of the model provide weak support for Hypothesis 1a.

One of the reasons for the weak performance of the cubic regression is that it implicitly relies on the assumption that observations are uniformly distributed across the domain of the explanatory variable. Consequently, when many observations are clustered over a small interval of ownership levels, this interval would have a disproportionately high weight in determining the curvature of the ownership-sensitivity relationship. As a consequence, other regions of ownership (those with a relatively smaller number of observations) will be given a smaller weight, which can distort the curvature and result in the estimated equation failing to pick up the true relationship.

Given that the distribution of ownership levels is highly skewed (Table 4, Panel B), we also estimate a piecewise linear regression model that relates investment-cash flow sensitivity to insider 
ownership. The choice of the cut-off points in the estimated piecewise linear equation is based on a grid search technique (we elect the specification with the highest goodness-of-fit). We obtain cut-off points of $16 \%$ and $22 \%$ (Table 7, Panel B). ${ }^{17}$ The piecewise linear model is sufficiently flexible to capture the changes in the slopes of the investment-cash flow sensitivity for weak, medium and strong insider ownership. The results of the model are as follows. When the levels of managerial ownership increase in the range [0-16\%), the sensitivity decreases by on average 0.005 for every additional percent of managerial ownership. This reduction is undone due to an increase in suboptimal investing when insider control increases further (within the range [16-22\%]). This implies that overinvestment problems are exacerbated by managerial entrenchment. The change in signs are in line with Hypothesis $1 \mathrm{~b}$ which states that cash flow sensitivity initially decreases with rising levels of insider ownership, but that entrenchment may lead to more suboptimal investment decisions for moderate insider ownership levels. At very high insider control levels of $22 \%$ or more (which is substantially above the median of the largest share stake, which equals $15 \%$ ), the negative impact of entrenchment disappears and investment decisions become again less dependent on the firm's liquidity. The fact that the cash flow sensitivity of investment initially decreases with rising insider ownership and subsequently increases, is consistent with the alignment/entrenchment hypotheses on insiders formulated by Morck et al. (1988) and McConnell and Servaes (1990) in the context of corporate valuation. The reduction in the sensitivity beyond $22 \%$ is consistent with Morck et al., 1988), as it reflects further alignment of managerial interests beginning to exceed existing entrenchment effects. The results of the regression model of Panel B support Hypothesis $1 \mathrm{~b}$ that the agency costs of free cash flow result in an S-shaped relationship between insider ownership and investment-cash flow sensitivity. A negative sign of the block ownership interaction term is consistent with Hypothesis 1c that the presence of outside blockholders attenuates the agency cost of free cash flow.

Panel $\mathrm{C}$ of Table 7 also investigates the impact of outside blockholders on the nonmonotonic relation. When outside blockholders do not own large equity stakes (their ownership is below the median), the non-monotonic relation is conserved: (i) there is a decreasing cash flow sensitivity at low levels of managerial ownership, (ii) cash flow sensitivity is substantially amplified 
when insider ownership rises further above $16 \%$, and (iii) cash flow sensitivity begins to decrease again when insiders' ownership is close to a blocking minority. The presence of large equity stakes owned by outsiders has three effects. First, it reduces the cash flow sensitivity in firms with no managerial ownership and in firms with high levels (more than 22\%). Second, it exacerbates the investment cash flow sensitivity in the region of managerial entrenchment (between 16\% and 22\%), which may indicate either that large outside blockholders are not able to curb managerial suboptimal investing or that they somehow extract private benefits of control at the expense of minority shareholders. Third, the presence of blockholders reduces the negative impact of insider ownership on the sensitivity of investment to internally generated cash flow for low levels of insider control. The latter result suggests that inside and outside ownership act in the relevant interval as substitutes in reducing the agency costs of free cash flow.

\section{[Insert Table 7 about here]}

Panels A and B of Table 7 confirm that the presence of major outside shareholders reduces the investment-cash flow sensitivity. As different types of outside blockholders may have different abilities and incentives to monitor management and influence the firm's investment decisions, Table 8 shows the impact on the investment-cash flow sensitivity of insiders, financial institutions, industrial and commercial companies, non-executive directors, the government and other blockholders (families and individuals not related to a director) ${ }^{18}$ Firstly, we still observe the effects of a growing alignment of managerial interests with those of shareholders at a low ownership level, entrenchment at its moderate level, and a further alignment at high stakes. Secondly, we show that blockholdings (by the government, financial institutions, and of more than $25 \%$ by industrial and commercial companies) attenuate the agency costs of free cash flow, which results in a lower investment-cash flow sensitivity. Surprisingly, non-executive directors owning substantial share stakes do not seem to influence the investment decision. If they were monitoring management dutifully, the fact that the corporate investment policy depends on the amount of cash flow generated would be reduced. If they support the incumbent management's decisions (Franks et al., 2001), we would have expected to see a higher degree of cash flow sensitivity. The non-significance of those parameter estimates in Table 8 may result from the fact that, across the sample, both effects may 
neutralize one another. Our findings of Table 8 do not contradict the free cash flow-based explanation as formulated by Hypotheses $1 \mathrm{~b}$ and 1c. The evidence also does not reject Hypothesis $2 \mathrm{~b}$ : the negative relationship between investment-cash flow sensitivity in the presence of major blockholdings held by financial institutions is consistent with the asymmetric information theory.

\section{[Insert Table 8 about here]}

In Table 9, we analyze the impact of corporate growth perspectives on cash flow sensitivity for firms with and without insider control. In the absence of insider control, the investment-cash flow sensitivity more than triples (from 0.031 to 0.099 ) in companies with high growth perspectives. This finding contradicts Hypothesis 1d, which states that the sensitivity is expected to be more outspoken in mature, firms with relatively low market-to-book values. The fact that there is a higher cash flow sensitivity is in line with Hypothesis 2c, which relates high sensitivity in high- $q$ firms to underinvestment problems. The reason why underinvestment is a problem especially in high- $q$ firms results from asymmetric information between the firm and the capital markets and from the fact that the fact that high growth firms have fewer tangible assets as collateral (Almeida and Campello, 2004).

We also document that insider ownership reduces the investment sensitivity to corporate liquidity both in high- $q$ and low- $q$ firms by about one third. In an agency framework, we would have expected to see the declining cash flow sensitivity along with rising insider ownership more clearly in firms with low growth since in mature firms it may be more difficult to generate positive NPV investment opportunities. As Tables 7 and 8 document that the presence of blockholders can also have an effect on the investment decision. Consequently, in order to further investigate the impact of Tobin's $q$ on the investment-cash flow sensitivity, we analyze relative managerial voting power as measured by Shapley values for high and low growth firms in Table 10 (Panel C), that is, when we apply the SV approach.

[Insert Table 9 about here]

A high Shapley value (see Section 4.1) for the management indicates that insiders have large ownership stakes and are pivotal in the formation of shareholder coalitions. In Table 10, we present 
the analysis for three levels of insider control: low $(\mathrm{SV}=0)$, moderate $(0<\mathrm{SV}<1)$, and high $(\mathrm{SV}=$ 1). Panel A exhibits that the investment decision of firms in which the management has no voting power is significantly positively related to the internally generated funds of the firm. The (initially) negative relationship between insiders' relative voting power and investment-cash flow sensitivity is sustained. However, these results do not provide evidence of managerial entrenchment as there is no statistical difference between the effect of SVs being between 0 and 1, and the effect of those equal to 1 (respectively, intermediate and strong relative voting power). These findings corroborate Hypothesis 1a. At low levels of control, investments are strongly influenced by available cash flow. At increasing levels, cash flow sensitivities decrease substantially (from 0.070 to 0.023 or 0.027 ).

Table 10 also tests in Panel B how cash flow sensitivities change with rising insider relative ownership for firms with a high probability of being liquidity constrained (they neither increase dividends nor repurchase equity). Henceforth, we label such firms as 'liquidity constrained' although Kaplan and Zingales (1997) show that more restrictive definitions could be used. ${ }^{19}$ We find a low positive correlation between investment and cash flow in firms which are not liquidity constrained and in which there is no insider control. In liquidity constrained firms, the investment-cash flow sensitivity is almost four times stronger than in firms increasing the payout $(0.135$ versus 0.036$)$. This evidence fails to reject Hypothesis 3, according to which investment is sensitive to cash due to liquidity constraints. This suggests that management faces a wedge between the costs of internal and external financing and this wedge makes them forgo some investments when the amount of internally generated funds is insufficient. Panel B also shows that intermediate and strong relative voting power exerted by insiders reduces the investment cash-flow sensitivity primarily in the subsample of the liquidity constrained firms (as the coefficients of the interaction terms of cash flow, liquidity constraints and insider control classes are significant and negative). The latter result is consistent with the free cash flow theory.

Finally, Panel $\mathrm{C}$ of Table 10 examines the investment decisions for high and low growth firms subject to differing levels of relative insider voting power. We find that in both high and low growth firms without insider control, the investment decision is closely related to firms' cash flow. Still, in the former firms, the investment-cash flow sensitivity is three times stronger. Relative insider 
voting power reduces the sensitivity substantially, which indicates that the agency costs theory of free cash flow appears, in general, to be a more plausible explanation than the asymmetric information hypothesis. The latter hypothesis, however, may partially explain the observed high cash flow sensitivity of investment of high- $q$ firms.

\section{[Insert Table 10 about here]}

In order to corroborate the results specified above, we further examine whether or not efficient firms invest more when the available internally generated funds are abundant. Efficient firms are firms for which the growth perspectives measured by Tobin's $q$ are close to the optimally achievable (hypothetical) q, which we call efficient $q$. In the methodology Subsection 4.4.2, we describe that the stochastic frontier of efficient $q$ 's depends on corporate size, investment, turnover, operating margin and leverage. In addition, part of the error term of this model was modeled by insider and outsider ownership concentration. We call firms close to efficient frontier of optimal $q$ 's, 'efficient firms'. This correction to Tobin's $q$ may be important because firms with high $q$ may significantly underperform their optimally achievable $q$ whereas firms with low $q$ may be close to their optimum.

In Panel A of Table 11, we show that investment in firms with low technical efficiency strongly depends on the available cash flow. The dependence of investment on cash is substantially reduced (by 40\%) in firms with high technical efficiency or, in other words, in firms which optimally deploy their assets and achieve a Tobin's $q$ close to their (hypothetically) highest achievable one. This finding is consistent with both Hypotheses 1e and 2d.

In order to disentangle the impact of the agency costs of free cash flow and of asymmetric information, we estimate the investment equation including both the efficiency and growth dummies. ${ }^{20}$ We find that higher efficiency has a similar effect on the investment-cash flow sensitivity of both groups of firms (efficient firms' cash flow sensitivity of investment is reduced by 0.031 and by 0.061 for low- $q$ and high- $q$ firms, respectively; see Panel B). ${ }^{21}$ This indicates that less efficient low- $q$ firms suffer from higher agency cost of free cash flow, which is consistent with Hypothesis 1e. As the high growth firms (high efficient $q$ ) are unlikely to be affected by free cash flow problems, the 
analogous negative relationship between efficiency and investment-cash flow sensitivity indicates that these firms are affected by asymmetric information problems (Hypothesis $2 \mathrm{~d}$ ).

[Insert Table 11 about here]

Finally, we test Hypothesis 3 to verify whether liquidity constraints are the main reason for the observed investment-cash flow sensitivity in our sample. Cash flow sensitivity is expected to be more strongly positive in liquidity constrained firms. In Table 12, we classify firms that are not liquidity constrained as those firms which return free cash flow to the shareholders by repurchasing shares (Panel A) and by increasing the dividend payout (Panel B). We find that the cash flow sensitivity is reduced in firms expected not to suffer from liquidity constraints. The cash flow sensitivity of firms that buy back their equity decreases by 0.004 for every $10 \%$ of repurchased equity value. Firms that increase dividends or keep them at the same level exhibit investment-cash flow sensitivity which is lower by 0.194 , and 0.162 , respectively, from the sensitivity of companies that reduce their level of cash disbursements. Finally, the sensitivity of firms that are classified as financially constrained (i.e. those reducing dividends/keeping them at a constant level and not repurchasing equity) is higher by 0.047 than the measure calculated for their non-constrained counterparts (Panel C). These findings support Hypothesis 3, according to which liquidity constraints, and not other factors - such as cash flow being a proxy for investment opportunities - are the main reason for the observed investment-cash flow sensitivity.

[Insert Table 12 about here]

\section{Conclusions}

This paper has investigated the investment-cash flow sensitivity of a large sample of firms listed on the London Stock Exchange in the 1990s. In general, we confirm earlier evidence that investment is strongly cash flow sensitive. Furthermore, we find that a cash flow-dependent investment policy results mainly from agency problems. The significantly positive relationship between investmentcash flow sensitivity and insider ownership is S-shaped and consistent with Morck et al. (1988). The alignment of interests for initially increasing ownership levels is observed both for firms with low and high growth opportunities. At moderate levels of insider ownership, cash flow sensitivity rises, 
which may be explained by the fact that insiders become more entrenched and may be able to enjoy private benefits of control. For high insider ownership levels, that is, when management internalizes a large fraction of the changes in the firm's value resulting from their actions, the investment-cash flow sensitivity decreases. Comparable results are obtained when we analyze the impact of relative insider control, as measured by Shapley values, which take into account the distribution of voting rights over both insiders and outside blockholders.

Subsequently, we find that outside blockholders do have an impact on the investment policy. Outside blockholders, such as financial institutions, the government, and industrial corporations (only at high control levels), reduce the cash flow sensitivity of investment via effective monitoring. Furthermore, the negative relationship between cash flow sensitivity and the ownership of financial institutions is consistent with the asymmetric information theory: institutions holding an equity block appear to reduce the informational asymmetry between the firm and capital markets.

We also find a negative relationship between the investment-cash flow sensitivity and corporate efficiency. Lower efficiency in the subsample of low- $q$ firms associated with a higher cash flow sensitivity of investment indicates that less efficient firms suffer from higher agency cost of free cash flow. An analogous relationship for high- $q$ companies indicates that they may suffer from informational asymmetries.

Finally, we show the investment policy of companies that are expected not to be liquidity constrained does not depend on the generated periodic cash flow. This result supports the view that the presence of liquidity constraints is a precondition for the observed cash flow sensitivity.

The results of this paper indicate that the agency costs of free cash flow appear to be the main source of the investment-cash flow sensitivity of the UK listed corporations in the post-Cadbury period. Therefore, from a policy perspective, it seems essential to pursue the further alignment of interests of managers and shareholders by stimulating effective shareholder monitoring and pay-forperformance schemes. Furthermore, our results indicate promising avenues for future research. Firstly, one can attempt to incorporate managerial remuneration and turnover in the investment model to analyze to what extent the disciplining devices have already translated into efficient 
investment policies. Secondly, an interesting research opportunity is to analyze the changes in the cash flow sensitivity of investment in the aftermath of (voluntary) changes in corporate disclosure. 


\section{References}

Almeida, H., and M. Campello, 2002, 'Financial Constraints and Investment-Cash Flow Sensitivities: New Research Directions', Working Paper, New York University.

Almeida, H., and M. Campello, 2004, 'Financial Constraints, Asset Tangibility, and Corporate Investment', Working Paper, New York University.

Alti, A., 2003, 'How Sensitive Is Investment to Cash Flow When Financing Is Frictionless?', Journal of Finance 58, pp. 707-722.

Battese, G. E., and T. J. Coelli, 1995, 'A Model for Technical Inefficiency Effects in a Stochastic Frontier Production Function for Panel Data', Empirical Economics 20, pp. 325-332.

Bernanke, B., and M. Gertler, 1989, 'Agency Costs, Net Worth and Business Fluctuations', American Economic Review 73, pp. 257-76.

Boyle, G. W., and G. A. Guthrie, 2003, 'Investment, Uncertainty, and Liquidity', Journal of Finance 58, pp. 2143-2166.

Cadbury Committee, 1992, 'The Code of Best Practice', Gee and Co. Ltd., London.

Carpenter, R. E., 1995, 'Finance Constraints of Free Cash Flow? A New Look at the Life Cycle Model of the Firm', Empirica 22, pp. 185-209.

Chung, K. and J.-K. Kim, 1999, 'Corporate Ownership and the Value of a Vote in an Emerging Market', Journal of Corporate Finance 5, pp. 35-54.

Cleary, S., 1999, 'The Relationship between Firm Investment and Financial Status', Journal of Finance 54, pp. 673-691.

Conyon, M., and K. Murphy, 2000, 'The Prince and the Pauper? CEO Pay in the US and the UK', Economic Journal 110, pp. 640-671.

Correia da Silva, L., M. Goergen and L. Renneboog, 2004, 'Dividend Policy and Corporate Governance', Oxford: Oxford University Press.

Crespi, R. and L. Renneboog, 2002, 'Coalition Formation and Shareholder Monitoring in the UK', CentER Discussion Paper, Tilburg University.

Degryse, H., and A. de Jong, 2000, 'Investment Spending in the Netherlands: The Impact of Liquidity and Corporate Governance', CentER Discussion Paper, Tilburg University.

Dyck, A. and L. Zingales, 2004, 'Private Benefits of Control: An International Comparison, Journal of Finance 59, pp. 537-600.

Demsetz, H. , 1983, 'The Structure of Ownership and the Theory of the Firm', Journal of Law and Economics 56, pp. 375-393.

Fazzari, S. M., R. G. Hubbard, and B. C. Petersen, 1988, 'Financing Constraints and Corporate Investment', Brookings Papers on Economic Activity 1, pp. 141-195.

Fazzari, S. M., R. G. Hubbard, and B. C. Petersen, 2000, 'Investment-Cash Flow Sensitivities Are Useful: A Comment on Kaplan and Zingales', Quarterly Journal of Economics 115, pp. 695-705.

Fazzari, S. M., and B. C. Petersen, 1993, 'Working Capital and Fixed Investment: New Evidence on Financing Constraints', RAND Journal of Economics 24, pp. 328-342.

Felsenthal, D. and M. Machover, 1998, 'The Measurement of Voting Power', Edward Elgar.

Franks, J., C. Mayer, and L. Renneboog, 2001, 'Who Disciplines the Management of Poorly Performing Companies?', Journal of Financial Intermediation 10, pp. 209-248.

Goergen, M. and L. Renneboog, 2001, 'Investment Policy, Internal Financing and Ownership Concentration in the UK', Journal of Corporate Finance 7, pp. 257-284.

Gomes, J., 2001, 'Financing Investment', American Economic Review 91, pp. 1263-1285. 
Greene, W.H., 2002, 'Econometric Analysis' (5th edition), Prentice Hall.

Greenwald, B., J. Stiglitz and A. Weiss, 1984, 'Informational Imperfections and Macroeconomic Fluctuations', American Economic Review Papers and Proceedings 74, pp. 194-199.

Grossman, S. J., and O. D. Hart, 1980, 'Takeover Bids, the Free Rider Problem and the Theory of the Corporation’ Bell Journal of Economics 11, pp. 42-64.

Grossman, S. J., and O. D. Hart, 1982, 'Corporate Financial Structure and Managerial Incentives', in: The Economics of Information and Uncertainty, McCall, J.J. (ed.), University of Chicago Press.

Gugler, K., 2003, 'Corporate Governance and Investment', International Journal of the Economics of Business, 10, pp. 261-289.

Gugler, K., and B. B. Yurtoglu, 2003, ‘Average Q, Marginal Q, and the Relation Between Ownership and Performance', Economics Letters 78, pp. 379-384.

Habib, M. A., and A. P. Ljungqvist, 2005, 'Firm Value and Managerial Incentives', Journal of Business, forthcoming.

Haid, A., and J. Weigand, 2001, 'R\&D Investment, Liquidity Constraints, and Corporate Governance', Jahrbücher für Nationalökonomie und Statistik, 221, pp. 145-167.

Hadlock, C. J., 1998, 'Ownership, Liquidity and Investment', RAND Journal of Economics 29, pp. 487-508.

Hoshi, T., A. Kashyap, and D. Scharfstein, 1991, 'Corporate Structure, Liquidity and Investment: Evidence from Japanese Industrial Groups’, Quarterly Journal of Economics 20, pp. 33-60.

Hubbard, R. G., 1999, 'Capital-Market Imperfections and Investment', Journal of Economic Literature 36, pp. 193-225.

Jensen, M., 1986, 'Agency Costs of Free Cash Flow, Corporate Finance and Takeovers', American Economic Review Papers and Proceedings 76, pp. 323-329.

Jensen, M., 2001, 'Value Maximization, Stakeholder Theory and the Corporate Objective Function', European Financial Management 7, pp. 297-317.

Jensen, M., and W. Meckling, 1976, 'Theory of the Firm: Managerial Behavior, Agency Costs, and Ownership Structure', Journal of Financial Economics 3, pp. 305-360.

Johnson, S., R. La Porta, F. Lopez-de-Silanes and A. Shleifer, 2000, 'Tunnelling', American Economic Review 90, pp. 22-27.

Kadapakkam, P., P. Kumar and L. Riddick, 1998, 'The Impact of Cash Flows and Firm Size on Investment: The International Evidence', Journal of Banking and Finance 22, pp. 293-320.

Kahn C., and A. Winton, 1998, 'Ownership Structure, Speculation, and Shareholder Intervention', Journal of Finance 53, pp. 99-129.

Kaplan, S. N., and L. Zingales, 1997, 'Do Investment-Cash Flow Sensitivities Provide Useful Measures of Financing Constraints?', Quarterly Journal of Economics 20, pp. 169-215.

Kathuria, R. and D.C. Mueller, 1995, 'Investment and Cash Flow: Asymmetric Information or Managerial Discretion', Empirica 22, pp. 211-234.

Lasfer, M., 1995, 'Agency Costs, Taxes and Debt: The UK Evidence, European Financial Management 1, pp. 265-285.

Lasfer, M., and M. Faccio, 1999, 'Managerial Ownership, Board Structure and Firm Value: The UK Evidence', Working paper, Cass Business School.

McConnell, J., and H. Servaes, 1990, 'Additional Evidence on Equity Ownership and Corporate Value’, Journal of Financial Economics 27, pp. 595-612.

Modigliani, F., and M. H. Miller, 1958, 'The Cost of Capital, Corporation Finance and the Theory of Investment', American Economic Review 48, pp. 261-297. 
Morck, R., A. Schleifer, and R. Vishny, 1988, 'Management Ownership and Market Valuation: An Empirical Analysis', Journal of Financial Economics 20, pp. 293-315.

Morgado, A., and J. Pindado, 2003, 'The Underinvestment and Overinvestment Hypotheses: an Analysis Using Panel Data', European Financial Management 9, pp. 163-177.

Moyen, N., 2004, 'Investment-Cash Flow Sensitivities: Constrained versus Unconstrained Firms', Journal of Finance 59, pp. 2061-2092.

Mudambi, R., and C. Nicosia, 1998, 'Ownership Structure and Firm Performance: Evidence from the UK Financial Services Industry’, Applied Financial Economics 8, pp. 175-180.

Myers, S., 1977, 'Determinants of Corporate Borrowing', Journal of Financial Economics 5, pp. 147-175.

Myers, S., 1984, 'The Capital Structure Puzzle', Journal of Finance 39, pp. 575-592.

Myers, S., and N. Majluf, 1984, 'Corporate Financing and Investment Decisions When Firms Have Information That Investors Do Not Have', Journal of Financial Economics 13, pp. 187-221.

Pindado, J., and C. de la Torre, 2004, 'The Effect of Ownership Structure on Underinvestment and Overinvestment Processes', EFMA 2004 Basel Meetings Paper.

Renneboog, L. and G. Trojanowski, 2004, 'The Managerial Labour Market and the Governance Role of Shareholder Control Structures in the UK', CentER Discussion Paper, Tilburg University.

Shapley, L., 1953, 'A Value for $n$-Person Games', in: Contributions to the Theory of Games II (Annals of Mathematics Studies 28), Kuhn, H. and A. Tucker (eds.), Princeton University Press.

Shleifer, A., and R. W. Vishny, 1986, 'Large Shareholders and Corporate Control', Journal of Political Economy 94, pp. 461-488.

Shleifer, A., and R. W. Vishny, 1997, 'A Survey of Corporate Governance', Journal of Finance 52, pp. 737-783.

Short, H., and K. Keasey, 1999, 'Managerial Ownership and the Performance of Firms: Evidence from the UK', Journal of Corporate Finance 5, pp. 79-101.

Stiglitz, J., and A. Weiss, 1981, 'Credit Rationing in Markets with Imperfect Information', American Economic Review 71, pp. 393-410.

Stulz, R., 1990, 'Managerial Discretion and Optimal Financing Policies', Journal of Financial Economics 26, pp. 3-27.

Vogt, S. C., 1994, 'The Cash Flow/Investment Relationship: Evidence from US Manufacturing Firms', Financial Management 23, pp. 3-20. 
Table 1

Financial variables - descriptive statistics.

Descriptive statistics for the sample of 985 UK firms over the entire sample period. $I_{t}$ denotes investment in fixed assets (change in the net fixed assets plus depreciation). $K_{t-1}$ denotes the beginning-of-the-year net fixed assets. $C F_{t}$ denotes cash flow. Sales ${ }_{t}$ denotes total revenues. $L E V_{t}$ is the ratio of book value of debt to market value of the firm (market value is estimated as total assets minus book value of equity plus market capitalization). $M V_{t} / B V_{t}$ stands for the market-to-book value ratio (market value is estimated as total assets minus book value of equity plus market capitalization). $Q^{\text {eff }}{ }_{t}$ denotes the efficient Tobin's $q$ and $E F F_{t}$ is a technical efficiency parameter (see Subsection 4.2.2). OperMar ${ }_{t}$ denotes the ratio of operating income before depreciation to revenues. PAYOUT $T_{t}$ is the ratio of dividends to earnings before interest and taxes. $D I V_{t}$ denotes dividends. $D \_I N C R_{t}$ is the dummy corresponding to dividend increase. $D \_Z E R O_{t}$ is the dummy corresponding to constant dividend. $B B A C K_{t}$ denotes the value of repurchased stock. $B B_{-} E Q_{t}$ represents the ratio of market value of repurchased stock to book equity. Number of firms: 985 . Number of firm-years: 4416.

Panel A: Corporate investment, size and leverage.

\begin{tabular}{lrrrrrrrrr}
\hline & Mean & Std. Dev. & Min & Max & $25 \%$ & Median & $75 \%$ Skewness & Kurtosis \\
\hline$I_{t}$ & 3399 & 10249 & -11800 & 36945 & -311 & 404 & 3459 & 2.026 & 7.281 \\
$K_{t-1}$ & 68259 & 135466 & 917 & 549200 & 4781 & 13690 & 50258 & 2.731 & 9.437 \\
$I_{t} / K_{t-1}$ & 0.097 & 0.246 & -0.279 & 0.793 & -0.040 & 0.044 & 0.175 & 1.246 & 4.598 \\
CF $_{t} / K_{t-1}$ & 0.779 & 1.173 & -0.612 & 4.477 & 0.140 & 0.420 & 0.951 & 1.905 & 6.302 \\
Sales $_{t}$ & 393355 & 1805980 & 1 & $4.47 \mathrm{E}+07$ & 24118 & 66276 & 197918 & 15.180 & 290.878 \\
LEV $_{t}$ & 0.398 & 0.207 & 0.002 & 0.991 & 0.240 & 0.373 & 0.542 & 0.423 & 2.559 \\
\hline
\end{tabular}

Panel B: Growth opportunities and operating performance.

\begin{tabular}{lrrrrrrrrr}
\hline & Mean & Std. Dev. & Min & Max & $25 \%$ & Median & $75 \%$ Skewness & Kurtosis \\
\hline$M V_{t} / B V_{t}$ & 1.872 & 1.841 & 0.363 & 46.652 & 1.091 & 1.451 & 2.033 & 9.669 & 170.014 \\
$Q^{\text {eff }}{ }_{t}$ & 3.610 & 6.675 & 0.385 & 196.488 & 1.213 & 1.672 & 2.678 & 8.696 & 162.171 \\
EFF $_{t}$ & 0.846 & 0.259 & 0.100 & 1.000 & 0.871 & 0.940 & 0.986 & -2.296 & 6.794 \\
OperMar $_{t}$ & 0.068 & 0.101 & -0.206 & 0.254 & 0.029 & 0.071 & 0.122 & -0.743 & 4.279 \\
\hline
\end{tabular}

Panel C: Dividend payout and buy-backs.

\begin{tabular}{|c|c|c|c|c|c|c|c|c|c|}
\hline & Mean & Std. Dev & Min & $\operatorname{Max}$ & $25 \%$ & Median & \multicolumn{2}{|c|}{$75 \%$ Skewness } & Kurtosis \\
\hline$\overline{\mathrm{PAYOUT}_{t}}$ & 0.202 & 0.185 & -0.121 & 0.626 & 0.055 & 0.198 & 0.302 & 0.445 & 2.832 \\
\hline$D I V_{t}$ & 9330.7 & 44108.6 & 0 & 774999 & 220 & 1034 & 3728 & 10.751 & 139.395 \\
\hline$D_{-} I N C R_{t}$ & 0.701 & 0.496 & 0 & 1 & 0 & 1 & 1 & -0.787 & 1.619 \\
\hline$D \_Z E R O_{t}$ & 0.162 & 0.309 & 0 & 1 & 0 & 0 & 0 & 2.388 & 6.705 \\
\hline Number of & $c k s$ & 323 & & & & & & & \\
\hline$B B A C K_{t}$ & 1035 & 17647 & 0 & 945000 & 0 & 0 & 0 & 35.534 & 1640.027 \\
\hline$B B \_E Q_{t}$ & 0.007 & 0.057 & 0 & 0.804 & 0 & 0 & 0 & 11.458 & 147.598 \\
\hline
\end{tabular}


Table 2

Corporate investment levels over time.

Descriptive statistics on the level of corporate investment, $I_{t}$, for the sample of 985 UK firms for period 19931998. The number of firm-years: 4416.

\begin{tabular}{lccccccc}
\hline & 1993 & 1994 & 1995 & 1996 & 1997 & 1998 & All years \\
\hline No Obs. & 761 & 809 & 854 & 882 & 902 & 204 & 4416 \\
Mean & 2077 & 2717 & 5027 & 3255 & 3357 & 5067 & 3399 \\
Median & 74 & 425 & 960 & 345 & 337 & 1098 & 404 \\
Std. Dev & 9044 & 9130 & 11066 & 10454 & 10753 & 10999 & 10249 \\
\hline
\end{tabular}

Table 3

Ownership of the largest shareholder and of all the blockholders.

Ownership patterns in the sample companies calculated for the entire sample period. Panel A contains the data on the ownership of the single largest shareholder. Panel B describes the ownership by all shareholders whose stake is at least $5 \%$ of all shares outstanding. Panel C contains the statistics on Herfindahl index (HI) based on all blockholdings. HI is defined as $\Sigma^{N}\left(O W N_{i}\right)^{2}$, where $O W N_{i}$ is the ownership of $i$-th blockholder, and $i=1,2, \ldots$, $N$.

Panel A: Ownership stake of the largest shareholder.

\begin{tabular}{lcccccccc}
\hline & 1992 & 1993 & 1994 & 1995 & 1996 & 1997 & 1998 & All years \\
\hline Mean & 0.212 & 0.216 & 0.214 & 0.212 & 0.206 & 0.205 & 0.207 & 0.210 \\
Median & 0.151 & 0.156 & 0.153 & 0.151 & 0.159 & 0.159 & 0.153 & 0.155 \\
Std. Dev & 0.162 & 0.159 & 0.155 & 0.153 & 0.144 & 0.142 & 0.146 & 0.151 \\
Min & 0.050 & 0.050 & 0.050 & 0.050 & 0.050 & 0.050 & 0.051 & 0.050 \\
Max & 0.898 & 0.898 & 0.899 & 0.899 & 0.899 & 0.899 & 0.899 & 0.899 \\
\hline
\end{tabular}

Panel B: The accumulated ownership stakes of all blockholders.

\begin{tabular}{lcccccccc}
\hline & 1992 & 1993 & 1994 & 1995 & 1996 & 1997 & 1998 & All years \\
\hline Mean & 0.404 & 0.394 & 0.388 & 0.388 & 0.379 & 0.377 & 0.391 & 0.394 \\
Median & 0.385 & 0.380 & 0.375 & 0.378 & 0.374 & 0.360 & 0.384 & 0.379 \\
Std. Dev & 0.206 & 0.202 & 0.200 & 0.190 & 0.182 & 0.188 & 0.186 & 0.199 \\
Min & 0.050 & 0.050 & 0.050 & 0.050 & 0.050 & 0.050 & 0.051 & 0.050 \\
Max & 0.988 & 0.993 & 0.978 & 0.938 & 0.985 & 0.985 & 0.899 & 0.993 \\
\hline
\end{tabular}

Panel C: The Herfindahl index of all large ownership stakes.

\begin{tabular}{lcccccccc}
\hline & 1992 & 1993 & 1994 & 1995 & 1996 & 1997 & 1998 & All years \\
\hline Mean & 0.092 & 0.091 & 0.089 & 0.087 & 0.081 & 0.080 & 0.084 & 0.086 \\
Median & 0.046 & 0.047 & 0.047 & 0.046 & 0.046 & 0.046 & 0.045 & 0.046 \\
Std. Dev & 0.120 & 0.117 & 0.110 & 0.110 & 0.100 & 0.099 & 0.101 & 0.108 \\
Min & 0.003 & 0.003 & 0.003 & 0.003 & 0.003 & 0.003 & 0.003 & 0.003 \\
Max & 0.806 & 0.806 & 0.808 & 0.808 & 0.808 & 0.808 & 0.808 & 0.808 \\
\hline
\end{tabular}


Table 4

Ownership and control by category of shareholder.

Ownership patterns by category of owner calculated for the entire sample period. Panel A contains the data on the largest blockholdings. Panel B contains the ownership data categorized with respect to the identity of a shareholder. Panel C contains the data on the single largest blockholdings. Panel D shows Shapley values categorized by type of owner.

Panel A: Aggregate statistics.

\begin{tabular}{|c|c|c|c|c|c|c|c|c|c|c|}
\hline & Mean & $\begin{array}{c}\text { Stand. } \\
\text { Dev. }\end{array}$ & Min & Q25\% & Median & Q75\% & Max & Skewness & Kurtosis & $\begin{array}{c}\text { Firm } \\
\text { years } \\
\text { with data }\end{array}$ \\
\hline $\begin{array}{l}\text { Sum of all } \\
\text { stakes }\end{array}$ & 0.394 & 0.199 & 0.050 & 0.239 & 0.379 & 0.539 & 0.995 & 0.284 & 2.407 & 5631 \\
\hline $\begin{array}{l}\text { Largest share } \\
\text { stake }\end{array}$ & 0.210 & 0.151 & 0.050 & 0.110 & 0.155 & 0.257 & 0.899 & 1.679 & 5.537 & 5631 \\
\hline
\end{tabular}

Panel B: Sum of all equity stakes by category of owner.

\begin{tabular}{|c|c|c|c|c|c|c|c|c|c|c|}
\hline & Mean & $\begin{array}{l}\text { Stand. } \\
\text { Dev. }\end{array}$ & Min & Q25\% & Median & Q75\% & Max & Skewness & Kurtosis & $\begin{array}{c}\text { Firm } \\
\text { years } \\
\text { with data }\end{array}$ \\
\hline Fin.Institutions & 0.203 & 0.167 & 0 & 0.066 & 0.177 & 0.305 & 0.954 & 0.886 & 3.692 & 5631 \\
\hline Corporations & 0.044 & 0.118 & 0 & 0 & 0 & 0 & 0.929 & 3.526 & 16.738 & 5631 \\
\hline $\begin{array}{l}\text { Individuals/ } \\
\text { Families (no } \\
\text { insiders) }\end{array}$ & 0.025 & 0.068 & 0 & 0 & 0 & 0 & 0.698 & 3.864 & 22.022 & 5631 \\
\hline Government & 0.0003 & 0.004 & 0 & 0 & 0 & 0 & 0.131 & 18.309 & 381.774 & 5631 \\
\hline Insiders & 0.104 & 0.176 & 0 & 0 & 0 & 0.148 & 0.871 & 1.819 & 5.415 & 5631 \\
\hline $\begin{array}{l}\text { Non-Exec. } \\
\text { Dir. }\end{array}$ & 0.005 & 0.030 & 0 & 0 & 0 & 0 & 0.513 & 9.081 & 105.270 & 5631 \\
\hline
\end{tabular}

Panel C: Largest shareholding categorized by type of owner.

\begin{tabular}{|c|c|c|c|c|c|c|c|c|c|c|}
\hline & Mean & $\begin{array}{c}\text { Stand. } \\
\text { Dev. }\end{array}$ & Min & Q25\% & Median & Q75\% & $\operatorname{Max}$ & Skewness & Kurtosis & $\begin{array}{c}\text { Firm } \\
\text { years } \\
\text { with data }\end{array}$ \\
\hline Fin.Institutions & 0.158 & 0.110 & 0.050 & 0.100 & 0.131 & 0.173 & 0.899 & 2.975 & 14.408 & 3086 \\
\hline Corporations & 0.304 & 0.177 & 0.050 & 0.185 & 0.256 & 0.392 & 0.857 & 0.958 & 3.246 & 595 \\
\hline $\begin{array}{l}\text { Individuals/ } \\
\text { Families (no } \\
\text { insiders) }\end{array}$ & 0.169 & 0.112 & 0.050 & 0.089 & 0.134 & 0.239 & 0.698 & 1.666 & 6.747 & 236 \\
\hline Insiders & 0.287 & 0.169 & 0.050 & 0.156 & 0.239 & 0.384 & 0.870 & 0.880 & 2.864 & 1464 \\
\hline $\begin{array}{l}\text { Non-Exec. } \\
\text { Dir. }\end{array}$ & 0.185 & 0.101 & 0.055 & 0.121 & 0.156 & 0.239 & 0.502 & 1.280 & 4.574 & 93 \\
\hline \multicolumn{11}{|c|}{ Panel D: Shapley values categorized by type of owner. } \\
\hline & Mean & $\begin{array}{l}\text { Stand. } \\
\text { Dev. }\end{array}$ & Min & Q25\% & Median & Q75\% & $\operatorname{Max}$ & Skewness & Kurtosis & $\begin{array}{c}\text { Firm } \\
\text { years } \\
\text { with data } \\
\end{array}$ \\
\hline Fin.Institutions & 0.566 & 0.435 & 0 & 0 & 0.667 & 1 & 1 & -0.270 & 1.311 & 5631 \\
\hline Corporations & 0.104 & 0.276 & 0 & 0 & 0 & 0 & 1 & 2.669 & 8.618 & 5631 \\
\hline $\begin{array}{l}\text { Individuals/ } \\
\text { Families (no } \\
\text { insiders) }\end{array}$ & 0.056 & 0.179 & 0 & 0 & 0 & 0 & 1 & 3.948 & 19.097 & 5631 \\
\hline Insiders & 0.230 & 0.005 & 0 & 0 & 0 & 0 & 0.167 & 24.924 & 682.436 & 5631 \\
\hline $\begin{array}{l}\text { Non-Exec. } \\
\text { Dir. }\end{array}$ & 0.120 & 0.282 & 0 & 0 & 0 & 0 & 1 & 2.377 & 7.321 & 5631 \\
\hline
\end{tabular}


Table 5

Technical efficiency - the stochastic frontier model.

Specification of the stochastic efficient frontier model. The dependent variable in the main model (Panel A) is the market-to-book ratio, $M V_{t} / B V_{t}$. LnSales $s_{t}$ is the natural logarithm of revenues. $I_{t} / K_{t-1}$ represents the ratio of investment to the lagged capital stock. $K_{t-1} /$ Sales $_{t}$ is the capital intensity. OperMar $r_{t}$ is the operating margin, and $L E V_{t}$ denotes the total leverage calculated on the basis of the market value of equity. Panel B shows the parameters of the inefficiency model. The dependent variable is $v_{t}$, which is a non-negative random component (distributed according to the truncated normal distribution $N\left(Z_{t} m, \sigma_{v}{ }^{2}\right)$, where $Z_{t}$ denotes the vector of variables affecting the inefficiency level and $m$ is a vector of unknown parameters). INS $S_{t}$ is the insiders' share of stock. Block $k_{t}$ denotes the other blockholders' share of stock. Panel C contains descriptive statistics of technical efficiency, $E F F_{t}$, defined as one minus ratio of $v_{t}$ to $M V_{t} / B V_{t}$.

Panel A: Stochastic frontier model.

\begin{tabular}{lcccc}
\hline & Coefficient & Std. Error & t-statistic & $\mathrm{P}>|\mathrm{t}|$ \\
\hline lnSales $_{t}$ & 0.432 & 0.894 & 0.483 & 0.629 \\
$\left(\text { lnSales }_{t}\right)^{2}$ & -0.217 & 0.448 & -0.484 & 0.628 \\
$I_{t} / K_{t-1}$ & 0.004 & 0.002 & 1.777 & 0.076 \\
$K_{t-1}$ Sales $_{t}$ & -0.032 & 0.009 & -3.759 & 0.000 \\
OperMar $_{t}$ & -0.694 & 0.082 & -8.513 & 0.000 \\
LEV $_{t}$ & -0.352 & 0.108 & -3.248 & 0.001 \\
Const. & 0.503 & 0.173 & 2.909 & 0.004 \\
\hline
\end{tabular}

Panel B: Inefficiency model.

\begin{tabular}{lcccc}
\hline & Coefficient & Std. Error & t-statistic & P>|t| \\
\hline$I N S_{t}$ & 0.108 & 0.061 & 1.774 & 0.076 \\
$\left(I N S_{t}\right)^{2}$ & -0.672 & 0.760 & 0.884 & 0.377 \\
Block $_{t}$ & 0.153 & 0.108 & 1.415 & 0.157 \\
$\left(\text { Block }_{t}\right)^{2}$ & -0.116 & 0.560 & -0.207 & 0.836 \\
Const. & -0.324 & 0.043 & -7.451 & 0.000 \\
LR test of the one-side error $\left(\chi^{2}\right):$ & 42.59 & & \\
\hline
\end{tabular}

Panel C: Technical efficiency - descriptive statistics.

\begin{tabular}{lcrcccccrr}
\hline & Mean & Std. Dev. & Min & Max & $25 \%$ & Median & $75 \%$ & Skewness & Kurtosis \\
\hline$E F F_{t}$ & 0.846 & 0.259 & 0.100 & 1.000 & 0.871 & 0.940 & 0.986 & -2.296 & 6.794 \\
\hline
\end{tabular}


Table 6

Investment model with managerial and outside block ownership.

The investment model based on a fixed effects estimation. The dependent variable is the ratio of investment to the lagged capital stock, $I_{t} / K_{t-1}$. Panel A shows results for all firms. Panel B shows the estimation results with interaction terms including dummies related to insider ownership and outside block ownership. $M V_{t-1} / B V_{t-1}$ stands for beginning-of-the-period market-to-book ratio. $C F_{t} / K_{t-1}$ stands for cash flow divided by beginning-ofthe-period capital stock. $D_{-} I N S_{t}$ is a dummy variable which equals 1 if insider ownership exceeds median level. D_Block $k_{t}$ is a dummy variable which equals 1 if outside blockholders' ownership is above median.

Panel A: Investment model for all firm-years.

\begin{tabular}{lcccc}
\hline & Coefficient & Std. Error & t-statistic & $\mathrm{P}>|\mathrm{t}|$ \\
\hline$C F_{t} / K_{t-1}$ & 0.109 & 0.004 & 28.66 & 0.000 \\
$M V_{t-1} / B V_{t-1}$ & 0.001 & 0.019 & 0.05 & 0.964 \\
Const. & 0.049 & 0.040 & 1.25 & 0.212 \\
$\mathrm{R}^{2}$ - within & 0.257 & & $\mathrm{~F}(2,2508)$ & 433.90 \\
$\mathrm{R}^{2}$ - between & 0.275 & & Number of obs. & 3445 \\
$\mathrm{R}^{2}$ - overall & 0.265 & & Numb. of groups & 935 \\
\hline
\end{tabular}

Panel B: Sample with interaction dummies associated with high concentration of managerial ownership and high ownership concentration of other blockholders.

\begin{tabular}{lcccc}
\hline & Coefficient & Std. Error & t-statistic & $\mathrm{P}>|\mathrm{t}|$ \\
\hline$C F_{t} / K_{t-1}$ & 0.096 & 0.010 & 10.04 & 0.000 \\
$M V_{t-1} / B V_{t-1}$ & 0.002 & 0.015 & 0.12 & 0.904 \\
$C F_{t} / K_{t-1} * D_{-} I N S_{t}$ & -0.035 & 0.010 & -3.40 & 0.001 \\
$C F_{t} / K_{t-1} * D_{-}$Block & -0.048 & 0.011 & -4.39 & 0.000 \\
$C F_{t} / K_{t-1} * D_{-} I N S_{t}$ & 0.053 & 0.015 & 3.36 & 0.001 \\
$* D_{-}$Block & & & & \\
Const. & 0.097 & 0.031 & 3.21 & 0.001 \\
$\mathrm{R}^{2}$ - within & 0.134 & & F(5,2382) & 73.95 \\
$\mathrm{R}^{2}$ - between & 0.054 & & Number of obs. & 3312 \\
$\mathrm{R}^{2}$ - overall & 0.112 & & Numb. of groups & 935 \\
\hline
\end{tabular}


Table 7

The non-monotonic relation between ownership and cash flow.

Random effects specification of the basic investment model with interaction terms involving cash flow and the level of insider ownership. The dependent variable is the ratio of investment to the lagged capital stock, $I_{t} / K_{t-1}$. $M V_{t-1} / B V_{t-1}$ stands for beginning-of-the-period market-to-book ratio. $C F_{t} / K_{t-1}$ stands for cash flow divided by capital stock. INS $S_{t}$ is the percentage stake of ownership held by insiders, and Block $k_{t}$ is the stake of ownership held by other blockholders. INS16 $t$ is the fraction of insider ownership, INS $S_{t}$, lower than $16 \%\left(I N S 16_{t}=\right.$ $\left.\min \left[0.16 ; I N S_{t}\right]\right), I N S 1622_{t}$ is the fraction of insider ownership between $16 \%$ and $22 \%\left(I N S 1622_{t}=\right.$ $\left.\max \left[0 ; \min \left[I N S_{t^{-}}-0.16 ; 0\right]\right]\right), I N S 22_{t}$ is the fraction of insider ownership higher than $22 \%\left(I N S 22_{t}=\max \left[I N S_{t^{-}}\right.\right.$ $0.22 ; 0]) . D \_B l o c k_{t}$ is a dummy variable which equals 1 if outside blockholders' ownership is above median.

Panel A: The non-monotonic relation between cash flow sensitivity and insider control.

\begin{tabular}{lcccc}
\hline & Coefficient & Std. Error & t-statistic & $\mathrm{P}>|\mathrm{t}|$ \\
\hline$C F_{t} / K_{t-1}$ & 0.086 & 0.009 & 9.31 & 0.000 \\
$M V_{t-1} / B V_{t-1}$ & 0.011 & 0.011 & 0.97 & 0.330 \\
$C F_{t} / K_{t-1} * I N S_{t}$ & -0.183 & 0.106 & -1.73 & 0.084 \\
$C F_{t} / K_{t-1} *\left(I N S_{t}\right)^{2}$ & -0.016 & 0.488 & -0.03 & 0.974 \\
$C F_{t} / K_{t-1} *\left(I N S_{t}\right)^{3}$ & 0.259 & 0.624 & 0.42 & 0.678 \\
$C F_{t} / K_{t-1} *$ Block $_{t}$ & -0.064 & 0.056 & -1.13 & 0.257 \\
$C F_{t} / K_{t-1} *\left(\text { Block }_{t}\right)^{2}$ & 0.031 & 0.094 & 0.33 & 0.741 \\
$C o n s t$. & 0.099 & 0.037 & 2.67 & 0.008 \\
$\mathrm{R}^{2}$ - within & 0.140 & \multicolumn{3}{c}{$\chi^{2}(7)$} \\
$\mathrm{R}^{2}$ - between & 0.064 & Number of obs. & 471.13 \\
$\mathrm{R}^{2}$ - overall & 0.121 & Numb. of groups & 3312 \\
\hline
\end{tabular}

Panel B: Cash flow sensitivity and insider control at various ownership thresholds.

\begin{tabular}{|c|c|c|c|c|}
\hline & Coefficient & Std. Error & t-statistic & $\mathrm{P}>|\mathrm{t}|$ \\
\hline$C F_{t} / K_{t-1}$ & 0.088 & 0.006 & 13.98 & 0.000 \\
\hline$M V_{t-1} / B V_{t-1}$ & 0.012 & 0.012 & 1.03 & 0.303 \\
\hline$C F_{t} / K_{t-1} * I N S 16_{t}$ & -0.522 & 0.101 & -5.16 & 0.000 \\
\hline$C F_{t} / K_{t-1} * I N S 1622_{t}$ & 0.811 & 0.346 & 2.35 & 0.019 \\
\hline$C F_{t} / K_{t-1} * I N S 22_{t}$ & -0.249 & 0.091 & -2.73 & 0.006 \\
\hline$C F_{t} / K_{t-1} *$ Block $_{t}$ & -0.065 & 0.022 & -2.93 & 0.003 \\
\hline Const. & 0.100 & 0.037 & 2.71 & 0.006 \\
\hline $\mathrm{R}^{2}$ - within & 0.144 & & $\chi^{2}(6)$ & 487.92 \\
\hline $\mathrm{R}^{2}$ - between & 0.067 & & Number of obs. & 3312 \\
\hline $\mathrm{R}^{2}$ - overall & 0.124 & & Numb. of groups & 925 \\
\hline
\end{tabular}

Panel C: The impact of outsider blockholdings on sensitivity-insider ownership relationship.

\begin{tabular}{|c|c|c|c|c|}
\hline & Coefficient & Std. Error & t-statistic & $\mathrm{P}>|\mathrm{t}|$ \\
\hline$C F_{t} / K_{t-1}$ & 0.101 & 0.006 & 18.14 & 0.000 \\
\hline$M V_{t-1} / B V_{t-1}$ & 0.005 & 0.012 & 0.41 & 0.681 \\
\hline$C F_{t} / K_{t-1} * I N S 16_{t}$ & -0.767 & 0.125 & -6.12 & 0.000 \\
\hline$C F_{t} / K_{t-1} * I N S 1622_{t}$ & 0.516 & 0.427 & 1.21 & 0.227 \\
\hline$C F_{t} / K_{t-1} * I N S 22_{t}$ & -0.099 & 0.108 & -0.92 & 0.359 \\
\hline $\begin{array}{l}C F_{t} / K_{t-1} * I N S 16_{t} \\
* D_{-} \text {Block }_{t}\end{array}$ & 0.535 & 0.207 & 2.59 & 0.010 \\
\hline $\begin{array}{l}C F_{t} / K_{t-1} * I N S 1622_{t} \\
* D \_ \text {Block }_{t}\end{array}$ & 1.529 & 0.822 & 1.86 & 0.063 \\
\hline $\begin{array}{l}C F_{t} / K_{t-1} * I N S 22_{t} \\
* D \_ \text {Block }_{t}\end{array}$ & -0.940 & 0.461 & -2.04 & 0.041 \\
\hline$C F_{t} / K_{t-1} * D \_$Block $k_{t}$ & -0.048 & 0.007 & -6.66 & 0.000 \\
\hline Const. & 0.109 & 0.037 & 2.97 & 0.003 \\
\hline $\mathrm{R}^{2}$ - within & 0.156 & & $\chi^{2}(9)$ & 536.36 \\
\hline $\mathrm{R}^{2}$ - between & 0.073 & & Number of obs. & 3312 \\
\hline $\mathrm{R}^{2}$ - overall & 0.133 & & Numb. of groups & 925 \\
\hline
\end{tabular}


Table 8

Investment model with cash flow and piece-wise block ownership.

Fixed effects specification of the basic investment model with interaction terms involving cash flow and level of control held by different types of shareholder. The dependent variable is the ratio of investment to the lagged capital stock, $I_{t} / K_{t-1} . M V_{t-1} / B V_{t-1}$ stands for beginning-of-the-period market-to-book ratio. $C F_{t} / K_{t-1}$ stands for cash flow divided by capital stock. INS16 $t$ is the fraction of insider ownership, $I N S_{t}$, lower than $16 \%\left(I N S 16_{t}=\right.$ $\left.\min \left[0.16 ; I N S_{t}\right]\right)$, INS1622 $2_{t}$ is the fraction of insider ownership between $16 \%$ and $22 \%\left(I N S 1622_{t}=\right.$ $\left.\max \left[0 ; \min \left[I N S_{t^{-}}-0.16 ; 0\right]\right]\right), I N S 22_{t}$ is the fraction of insider ownership higher than $22 \%\left(I N S 22_{t}=\max \left[I N S_{t^{-}}\right.\right.$ $0.22 ; 0]) . F L_{t}$ is the fraction of ownership by financial institutions, $F_{t}$, lower than $25 \%\left(F L_{t}=\min \left[0.25 ; F_{t}\right]\right)$, $F H_{t}$ is the fraction of ownership by financial institutions higher than $25 \%\left(F H_{t}=\max \left[F_{t}-0.25 ; 0\right]\right)$. The remaining variables are defined analogously, with $I$ referring to industrial and commercial companies, $N E$ to non-executive directors, $O$ to other individuals, and $G$ to the government.

\begin{tabular}{lcccc}
\hline & Coefficient & Std. Error & t-statistic & $\mathrm{P}>|\mathrm{t}|$ \\
\hline$C F_{t} / K_{t-1}$ & 0.088 & 0.008 & 11.43 & 0.000 \\
$M V_{t-1} / B V_{t-1}$ & 0.013 & 0.015 & 0.84 & 0.401 \\
$C F_{t} / K_{t-1} * I N S 16_{t}$ & -0.713 & 0.129 & -5.52 & 0.000 \\
$C F_{t} / K_{t-1} * I N S 1622_{t}$ & 1.030 & 0.400 & 2.57 & 0.010 \\
$C F_{t} / K_{t-1} * I N S 22_{t}$ & -0.209 & 0.101 & -2.02 & 0.038 \\
$C F_{t} / K_{t-1} * F L_{t}$ & -0.090 & 0.051 & -1.79 & 0.010 \\
$C F_{t} / K_{t-1} * F H_{t}$ & -0.059 & 0.056 & -1.05 & 0.296 \\
$C F_{t} / K_{t-1} * I L_{t}$ & 0.909 & 0.118 & 7.72 & 0.000 \\
$C F_{t} / K_{t-1} * I H_{t}$ & -0.915 & 0.170 & -5.38 & 0.000 \\
$C F_{t} / K_{t-1} * N E L_{t}$ & 0.355 & 0.214 & 1.66 & 0.097 \\
$C F_{t} / K_{t-1} * N E H_{t}$ & 0.101 & 0.502 & 0.20 & 0.840 \\
$C F_{t} / K_{t-1} * O L_{t}$ & -0.309 & 0.198 & -1.57 & 0.118 \\
$C F_{t} / K_{t-1} * O H_{t}$ & 2.633 & 1.027 & 2.56 & 0.010 \\
$C F_{t} / K_{t-1} * G L_{t}$ & -62.041 & 7.705 & -8.05 & 0.000 \\
$C o n s t$ & 0.066 & 0.031 & 2.13 & 0.034 \\
$\mathrm{R}^{2}$ - within & 0.186 & & F(14, 2373) & 38.75 \\
$\mathrm{R}^{2}$ - between & 0.052 & & Number of obs. & 3312 \\
$\mathrm{R}^{2}$ - overall & 0.128 & & Number of groups & 925 \\
\hline
\end{tabular}

Table 9

Investment model with insider ownership and growth opportunities.

Fixed effects specification of the investment model. The dependent variable is the ratio of investment to the lagged capital stock, $I_{t} / K_{t-1}$. The model is estimated with interaction dummies related to insider ownership and growth opportunities. $M V_{t-1} / B V_{t-1}$ stands for beginning-of-the-period market-to-book ratio. $C F_{t} / K_{t-1}$ stands for cash flow divided by capital stock. $D_{-} I N S_{t}$ is a dummy variable which equals 1 if insider ownership exceeds median level. $D_{-} Q_{t-1}$ is a dummy variable which equals 1 if the beginning-of-the-period market-to-book ratio is above median.

\begin{tabular}{lcccc}
\hline & Coefficient & Std. Error & t-statistic & $\mathrm{P}>|\mathrm{t}|$ \\
\hline$C F_{/} / K_{t-1}$ & 0.031 & 0.006 & 4.90 & 0.000 \\
$M V_{t-1} / B V_{t-1}$ & -0.010 & 0.015 & -0.67 & 0.505 \\
$C F_{/} / K_{t-1} * D_{-} I N S_{t}$ & -0.010 & 0.012 & -0.79 & 0.428 \\
$C F_{/} / K_{t-1} * D_{-} Q_{t-1}$ & 0.066 & 0.009 & 6.99 & 0.000 \\
$C F_{/} / K_{t-1}$ & -0.017 & 0.015 & -1.12 & 0.261 \\
$* D_{-} I N S_{t} * D_{-} Q_{t-1}$ & & & 3.72 & \\
Const. & 0.112 & 0.030 & F(5, 2382) & 0.000 \\
$\mathrm{R}^{2}$ - within & 0.150 & & Number of obs. & 33.22 \\
$\mathrm{R}^{2}$ - between & 0.057 & & Numb. of groups & 925 \\
$\mathrm{R}^{2}$ - overall & 0.122 & & &
\end{tabular}


Table 10

Investment model with managerial SVs, liquidity constraints and growth opportunities.

Investment model with proxies for differing managerial Shapley values (SVs) for the entire sample (random effects specification), differing degree of liquidity constraints and differing degree of growth opportunities (both fixed effects specification). The dependent variable, $I_{t} / K_{t-1}$, is the ratio of investment to the lagged capital stock. $M V_{t-1} / B V_{t-1}$ stands for beginning-of-the-period market-to-book ratio. $C F_{t} / K_{t-1}$ stands for cash flow divided by capital stock. $D_{-} 0<S V<1_{t}$ is a dummy variable which equals 1 if managerial Shapley value is strictly positive and lower than $1 . D_{-} S V=1_{t}$ is a dummy variable which equals 1 if managerial Shapley value is $1 . D_{-} Q_{t}$. ${ }_{1}$ is a dummy variable which equals 1 if the beginning-of-the-period market-to-book ratio is above median. $D_{-} \operatorname{CONSTR}_{t}$ is a dummy variable which equals 1 if a firm is financially constrained, i.e. it reduces the dividend/keeps it at the constant level AND does not buy back its shares.

Panel A: All sample firms.

\begin{tabular}{|c|c|c|c|c|}
\hline & Coefficient & Std. Error & t-statistic & $\mathrm{P}>|\mathrm{t}|$ \\
\hline$C F_{t} / K_{t-1}$ & 0.070 & 0.003 & 20.79 & 0.000 \\
\hline$M V_{t-1} / B V_{t-1}$ & 0.015 & 0.011 & 1.35 & 0.179 \\
\hline$C F_{t} / K_{t-1} * D \_0<S V<1_{t}$ & -0.046 & 0.016 & -2.94 & 0.003 \\
\hline$C F_{t} / K_{t-1} * D \_S V=1_{t}$ & -0.043 & 0.007 & -6.63 & 0.000 \\
\hline Const. & 0.090 & 0.037 & 2.44 & 0.015 \\
\hline $\mathrm{R}^{2}$ - within & 0.140 & & $\chi^{2}(4)$ & 477.13 \\
\hline $\mathrm{R}^{2}$ - between & 0.069 & & Number of obs. & 3312 \\
\hline $\mathrm{R}^{2}$ - overall & 0.124 & & Numb. of groups & 925 \\
\hline
\end{tabular}

Panel B: Constrained vs. non-constrained firms.

\begin{tabular}{|c|c|c|c|c|}
\hline & Coefficient & Std. Error & t-statistic & $\mathrm{P}>|\mathrm{t}|$ \\
\hline$\overline{C F_{t} / K_{t-1}}$ & 0.036 & 0.005 & 7.59 & 0.000 \\
\hline$M V_{t-1} / B V_{t-1}$ & 0.014 & 0.015 & 0.92 & 0.346 \\
\hline$C F_{t} / K_{t-1} * D \_0<S V<1_{t}$ & -0.010 & 0.015 & -0.66 & 0.509 \\
\hline$C F_{t} / K_{t-1} * D_{-} S V=l_{t}$ & -0.017 & 0.011 & -1.56 & 0.119 \\
\hline$C F_{t} / K_{t-1} * D_{-} C O N S T R_{t-1}$ & 0.099 & 0.008 & 12.53 & 0.000 \\
\hline $\begin{array}{l}C F_{t} / K_{t-1} * D_{-} O<S V<1_{t} \\
* D_{-} C O N S T R_{t-1}\end{array}$ & -0.037 & 0.080 & -0.46 & 0.645 \\
\hline $\begin{array}{l}C F_{t} / K_{t-1} * D \_S V=1_{t} \\
* D_{-} C O N S T R_{t-1}\end{array}$ & -0.094 & 0.014 & -6.66 & 0.000 \\
\hline Const. & 0.073 & 0.030 & 2.43 & 0.015 \\
\hline $\mathrm{R}^{2}$ - within & 0.178 & & $\mathrm{~F}(7,2207)$ & 68.26 \\
\hline $\mathrm{R}^{2}$ - between & 0.036 & & Number of obs. & 3108 \\
\hline $\mathrm{R}^{2}$ - overall & 0.116 & & Numb. of groups & 894 \\
\hline
\end{tabular}

Panel C: Firms with high $q$ vs. firms with low $q$.

\begin{tabular}{|c|c|c|c|c|}
\hline & Coefficient & Std. Error & t-statistic & $\mathrm{P}>|\mathrm{t}|$ \\
\hline$\overline{C F_{t} / K_{t-1}}$ & 0.034 & 0.006 & 5.66 & 0.000 \\
\hline$M V_{t-1} / B V_{t-1}$ & -0.012 & 0.015 & -0.83 & 0.408 \\
\hline$C F_{t} / K_{t-1} * D_{-} 0<S V<1_{t}$ & -0.002 & 0.052 & -0.04 & 0.971 \\
\hline$C F_{t} / K_{t-1} * D \_S V=1_{t}$ & -0.029 & 0.013 & -2.21 & 0.027 \\
\hline$C F_{t} / K_{t-1} * D_{-} Q_{t-1}$ & 0.071 & 0.008 & 9.11 & 0.000 \\
\hline $\begin{array}{l}C F_{t} / K_{t-1} * D \_0<S V<1_{t} \\
* D \_Q_{t-1}\end{array}$ & -0.080 & 0.055 & -1.46 & 0.146 \\
\hline $\begin{array}{l}C F_{t} / K_{t-1} * D \_S V=1_{t} \\
* D \_Q_{t-1}\end{array}$ & -0.045 & 0.015 & -2.91 & 0.004 \\
\hline Const. & 0.112 & 0.030 & 3.76 & 0.000 \\
\hline $\mathrm{R}^{2}$ - within & 0.180 & & $F(7,2380)$ & 74.76 \\
\hline$R^{2}$ - between & 0.071 & & Number of obs. & 3312 \\
\hline $\mathrm{R}^{2}$ - overall & 0.146 & & Numb. of groups & 925 \\
\hline
\end{tabular}




\section{Table 11}

Investment model with technical efficiency.

Fixed effects specification of the investment model with the interaction terms involving technical efficiency. The dependent variable is the ratio of investment to the lagged capital stock, $I_{t} / K_{t-1} . M V_{t-1} / B V_{t-1}$ stands for beginning-of-the-period market-to-book ratio. $C F_{t} / K_{t-1}$ stands for cash flow divided by capital stock. $D_{-} E F F_{t-1}$ is a dummy variable which equals 1 if beginning-of-the-period technical efficiency (cf. subsection 4.4.2) is above median. $D_{-} Q_{t-1}^{\text {eff }}$ is a dummy variable which equals 1 if the beginning-of-the-period efficient $q$ is above median.

Panel A: Investment model with technical efficiency.

\begin{tabular}{lcccc}
\hline & Coefficient & Std. Error & t-statistic & $\mathrm{P}>|\mathrm{t}|$ \\
\hline$C F_{/} / K_{t-1}$ & 0.119 & 0.004 & 28.99 & 0.000 \\
$M V_{t-1} / B V_{t-1}$ & 0.010 & 0.020 & 0.52 & 0.606 \\
$C F_{/} / K_{t-1} * D_{-} E F F_{t-1}$ & -0.047 & 0.008 & 5.96 & 0.000 \\
$C o n s t$. & 0.045 & 0.039 & 1.14 & 0.255 \\
$\mathrm{R}^{2}$ - within & 0.267 & & $\mathrm{~F}(3,2507)$ & 305.06 \\
$\mathrm{R}^{2}$ - between & 0.259 & & Number of obs. & 3445 \\
$\mathrm{R}^{2}$ - overall & 0.270 & & Number of firms & 935 \\
\hline
\end{tabular}

Panel B: Investment model with technical efficiency and efficient $q$.

\begin{tabular}{|c|c|c|c|c|}
\hline & Coefficient & Std. Error & t-statistic & $\mathrm{P}>|\mathrm{t}|$ \\
\hline$C F_{t} / K_{t-1}$ & 0.175 & 0.027 & 6.46 & 0.000 \\
\hline$M V_{t-1} / B V_{t-1}$ & 0.019 & 0.020 & 0.99 & 0.322 \\
\hline$C F_{t} / K_{t-1} * D_{-} Q^{e f f}{ }_{t-1}$ & -0.056 & 0.027 & -2.08 & 0.037 \\
\hline$C F_{t} / K_{t-1} * D \_E F F_{t-1}$ & -0.031 & 0.032 & -0.97 & 0.330 \\
\hline $\begin{array}{l}C F_{t} / K_{t-1} * D_{-} E F F_{t-1} \\
* D_{-} Q^{\text {eff }}{ }_{t-1}\end{array}$ & -0.030 & 0.033 & -0.89 & 0.372 \\
\hline Const. & 0.019 & 0.040 & 0.46 & 0.643 \\
\hline $\mathrm{R}^{2}$ - within & 0.274 & & $\mathrm{~F}(5,2505)$ & 188.93 \\
\hline $\mathrm{R}^{2}$ - between & 0.254 & & Number of obs. & 3445 \\
\hline $\mathrm{R}^{2}$ - overall & 0.271 & & Number of firms & 935 \\
\hline
\end{tabular}


Table 12

Investment model for firms buying back equity and increasing dividends.

Fixed effects specification of the basic investment model with the interaction term involving cash flow and technical efficiency. The dependent variable is the ratio of investment to the lagged capital stock, $I_{t} / K_{t-1} . M V_{t-}$. ${ }_{1} / B V_{t-1}$ stands for beginning-of-the-period market-to-book ratio. $C F_{t} / K_{t-1}$ stands for cash flow divided by capital stock. $B B_{-} E Q_{t}$ is the ratio of the value of repurchased stock to equity capital. $D_{-} I N C R_{t}$ is a dummy variable indicating that the firm increases its dividends. $D \_Z E R O_{t}$ is a dummy variable indicating that the firm does not change its dividends. The firms with financing constraints of Panel $\mathrm{C}$, refrain both from buying back shares and from increasing their dividends. $D_{-} C O N S T R_{t}$ is a dummy variable which equals 1 if a firm is financially constrained, i.e. it reduces the dividend/keeps it at the constant level AND does not buy back its shares.

Panel A: Investment model with firms buying back shares.

\begin{tabular}{lcccc}
\hline & Coefficient & Std. Error & t-statistic & $\mathrm{P}>|\mathrm{t}|$ \\
\hline$C F_{\downarrow} / K_{t-1}$ & 0.111 & 0.004 & 28.81 & 0.000 \\
$M V_{t-1} / B V_{t-1}$ & -0.001 & 0.020 & -0.03 & 0.973 \\
$C F_{d} / K_{t-1} * B B_{-} E Q_{t-1}$ & -0.044 & 0.016 & -2.71 & 0.007 \\
Const. & 0.053 & 0.040 & 1.31 & 0.189 \\
$\mathrm{R}^{2}$ - within & 0.259 & & $\mathrm{~F}(3,2507)$ & 292.43 \\
$\mathrm{R}^{2}$ - between & 0.276 & & Number of obs. & 3445 \\
$\mathrm{R}^{2}$ - overall & 0.267 & & Numb. of groups & 935 \\
\hline
\end{tabular}

Panel B: Investment model with firms increasing dividend payout.

\begin{tabular}{lcccc}
\hline & Coefficient & Std. Error & t-statistic & $\mathrm{P}>|\mathrm{t}|$ \\
\hline$C F_{t} / K_{t-1}$ & 0.227 & 0.005 & 44.41 & 0.000 \\
$M V_{t-1} / B V_{t-1}$ & -0.003 & 0.017 & 0.19 & 0.850 \\
$C F_{t} / K_{t-1} * D_{-} I N C R_{t-1}$ & -0.194 & 0.007 & -27.49 & 0.000 \\
$C F_{t} / K_{t-1} * D_{-} Z E R O_{t-1}$ & -0.162 & 0.007 & -22.35 & 0.000 \\
Const. & 0.085 & 0.034 & 2.45 & 0.015 \\
$\mathrm{R}^{2}$ - within & 0.453 & & $\mathrm{~F}(4,2506)$ & 519.48 \\
$\mathrm{R}^{2}$ - between & 0.336 & & Number of obs. & 3445 \\
$\mathrm{R}^{2}$ - overall & 0.418 & & Numb. of groups & 935 \\
\hline
\end{tabular}

Panel C: Investment model with financing constraints.

\begin{tabular}{lcccc}
\hline & Coefficient & Std. Error & $\mathrm{t}$-statistic & $\mathrm{P}>|\mathrm{t}|$ \\
\hline$C F_{t} / K_{t-1}$ & 0.031 & 0.005 & 6.36 & 0.000 \\
$M V_{t-1} / B V_{t-1}$ & 0.006 & 0.018 & 0.31 & 0.757 \\
$C F_{t} / K_{t-1} *$ CONSTR & & 0.007 & 6.46 & 0.000 \\
Const. & 0.047 & 0.036 & 2.59 & 0.010 \\
$\mathrm{R}^{2}$ - within & 0.093 & & $\mathrm{~F}(3.2316)$ & 76.25 \\
$\mathrm{R}^{2}$ - between & 0.090 & & Number of obs. & 3223 \\
$\mathrm{R}^{2}$ - overall & 0.072 & & Numb. of groups & 904 \\
\hline
\end{tabular}


${ }^{1}$ Asset substitution and debt overhang problems - analyzed by Jensen and Meckling (1976) and Myers (1977), respectively - are associated with distortions in investment policy not related directly to conditions (i) and (ii) and, therefore, do not have a straightforward impact on the investment-cash flow sensitivity.

${ }^{2}$ In this place, it should be emphasized that the concepts of under- and overinvestment are broader than the scope of this paper.

${ }^{3}$ A related problem of debt rationing is described by Stiglitz and Weiss (1981) and Greenwald, Stiglitz and Weiss (1984). Here, the only way for the creditors to break even is to limit debt financing in order to balance the proportions of credit granted to risky and safe companies. As a result of such a credit rationing, some positive NPV projects are not undertaken in the resulting capital market equilibrium.

${ }^{4}$ The role of the Cadbury Committee was to prevent the reoccurrence of spectacular business failures characteristic for the decade of the 1980s. The committee, chaired by Sir Adrian Cadbury, was drawn from representatives from the top level of British industry, created a code of practice to assist UK corporations in defining and applying internal controls to limit their exposure to financial loss, from whatever cause. Whilst the recommendations themselves are not mandatory, all accounts of UK-listed companies must now clearly state whether or not the code has been followed and, if applicable, the reason for non-compliance has to be presented. For details, see Cadbury Committee (1992).

${ }^{5}$ As not only the impact of insider control in absolute numbers needs to be examined, we re-examine our research question by using Shapley values in order to capture relative control exerted by insiders.

${ }^{6}$ The assumption of liquidity constraints underlies both the free cash flow- and asymmetric information-based explanation of the positive relationship between cash flow and investment.

${ }^{7}$ Likewise, Morck, Shleifer and Vishny (1988) and McConnell and Servaes (1990) show that insider ownership has a non-linear impact on firm value.

${ }^{8}$ Beyond a certain ownership level another problem may occur: the expropriation of minority shareholders by large blockholders more severe conflict between majority and minority shareholders (Shleifer and Vishny, 1997; Johnson et al., 2000.)

${ }^{9}$ Similarly, in the presence of informational asymmetries the firm may face credit rationing in the debt markets (Stiglitz and Weiss, 1981).

${ }^{10}$ We use the UK definition of a director: a director is a person serving on the board of directors and can have an executive or non-executive position.

${ }^{11}$ Their large equity stake is partly explained by the fact that yearly a number of firms are floated on the stock exchange, amounting to $4 \%$ of all listed companies. At floatation, the initial (pre-IPO) shareholders retain an average accumulated shareholding of $62 \%$ (Goergen and Renneboog, 2001), which is gradually diluted over time.

${ }^{12}$ The Shapley value is a way to distribute the total surplus from cooperation to blockholders, assuming that they all collaborate. The amount that blockholder i receives if the value function $\mathrm{v}$ is being used is given by

$$
\phi_{i}(v)=\frac{1}{n !} \sum_{i \notin S \subseteq N}|S| !(n-|S|-1) !(v(S \cup\{i\})-v(S)),
$$

where $n$ is the number of blockholders and the sum extends over all subsets $S$ of the grand coalition $N$ not containing blockholder i. The formula implies that the compensation of blockholder $i$ is proportional to their contribution $v(S \cup\{i\})-v(S)$ scaled with all the possible different combinations of $N$ in which a coalition can be formed. We normalize the total payoff of a winning coalition to 1 . The remaining blockholders receive zero as a payoff (Felsenthal and Machover, 1998). Consequently, $v(S)=1$ if the coalition $S$ represents more than $50 \%$ of votes and $v(S)=0$ otherwise. A Shapley value attributable to blockholder $i$ can therefore be interpreted as the fraction of the payoff of the winning coalition received by this blockholder. In the context of this study, the winning coalition influences the investment decision. As differential voting behavior is motivated by different conceptions of future performance and private benefits under the incumbent management, the resisting blockholders (among which the equity owning incumbent management) are expected will suffer a reduction in financial returns and private benefits. We assume that atomistic shareholders do not participate in voting coalitions (Chung and Kim, 1999) and, therefore, we rescale the sum of the large share blocks to 100\% prior to calculating the SVs. The resulting SVs reflect the relative voting power whereby a winning coalition is expected to reach absolute control $(50 \%+1$ of the rescaled vote).

${ }^{13}$ Felsenthal and Machover (1998) also discuss several alternative power indices like the Deegan-Packel index and the Johnston index but illustrate the "extremely counter-intuitive 'pathological' behavior of these indices" (p. 211).

${ }^{14}$ Equations (1) and (2) are estimated in the following three steps: (i) running an OLS regression in order to obtain an unbiased estimate of the vector of parameters of (1), (ii) applying a grid search procedure determining 
the fraction of $\sigma_{v}{ }^{2} /\left(\sigma_{\varepsilon}^{2}+\sigma_{v}{ }^{2}\right)$ corresponding to the best fit of the OLS model, and (iii) performing an iterative procedure leading to the final joint maximum likelihood estimation of (1) and (2).

${ }^{15}$ Habib and Ljungqvist (2005) report the average efficiency of the 1992-1997 sample of 1487 US firms to be equal to 0.907 .

${ }^{16}$ For the sake of transparency, we suppress the cross-section subscript $i$.

${ }^{17}$ In the UK literature, we find that the following cut off points are chosen: $14 \%$ and $42 \%$ in Short and Keasey (1999), 13\% and 30\% in Mudambi and Nicosia (1998), and 20\% and 54\% in Lasfer and Faccio (1999).

${ }^{18}$ The chosen $25 \%$ threshold, which allows for changing slope of the cash flow sensitivity-ownership relationship for outside blockholders, represents a blocking minority. A shareholder controlling a blocking minority has an important say (holds a veto right) on changes in the acts of incorporation, changes in the voting rights composition etc.

${ }^{19}$ In the definition of liquidity constraints, Kaplan and Zingales also include qualitative information about the firm. Still, their study is based on a tiny sample and their approach cannot be imitated for large samples of long time windows.

${ }^{20}$ We proxy growth opportunities here with efficient $q$ in order to avoid the problem of Tobin's $q$ being a proxy for another explanatory variable, the firm's efficiency.

${ }^{21}$ Although the parameters of the two interaction terms are not significantly different from zero when considered separately, they are jointly statistically significant at $1 \%$ (with $F=9.45$ ). 